PALABRAS CLAVE

Capitalismo

Economía

Desarrollo económico

América Latina
Raúl Prebisch

Director de la Revista

de la CEPAL (1976-1986)
REVISTA DE LA CEPAL 96 - DICIEMBRE 2008

\section{Hacia una teoría de la transformación}

\author{
Raúl Prebisch
}

$\mathrm{C}$

on este artículo el autor pone fin a la serie que iniciara con "Crítica al capitalismo periférico" (publicado en el № 1), y continuara con "Estructura socioeconómica y crisis del sistema" ( $\left.N^{\circ} 6\right)$ y "Las teorías neoclásicas del liberalismo económico" ( $\left.N^{\circ} 7\right)$. Si en todos los anteriores su preocupación principal consistió en interpretar críticamente el funcionamiento del capitalismo periférico y demostrar la incapacidad de la teoría neoclásica para comprenderlo en profundidad, en este procura brindar los lineamientos que debería seguir la transformación de ese sistema.

Después de recordar los rasgos básicos de su crítica al funcionamiento del capitalismo en la periferia (Cap. I), esboza los criterios que deben orientar la transformación, los que, en suma, constituyen una síntesis de valores centrales del socialismo y del liberalismo (Cap. II). A continuación, plantea algunas cuestiones inevitables sobre las condiciones políticas de la transformación, por medio de las cuales reafirma el valor de la democracia como ideal de convivencia (Cap. III). Los capítulos inmediatamente siguientes (IV y V) están dedicados a completar sus planteamientos a través del análisis de problemas de la transformación vinculados a la técnica, la demanda, la estructura productiva, los rasgos específicos del capitalismo periférico, y otros. En los capítulos finales cambia un tanto su foco de análisis para tratar, por una parte, el papel de las relaciones centro-periferia en la transformación (Cap. VI); y, por otra, la crisis actual de los centros y sus repercusiones sobre la periferia (Cap. VII); para finalizar con unas reflexiones sobre ética, racionalidad y previsión (Cap. VIII).

Sus ideas centrales provocarán polémicas, no solo por quien las escribe, sino también porque giran alrededor de las controvertidas nociones de apropiación y uso social del excedente. Pero el autor está convencido de que la crisis actual no será superada con medidas superficiales; si se quiere salir de ella y construir una sociedad desarrollada, democrática y equitativa, será necesario que la transformación llegue hasta las raíces del sistema. 


\section{Primera parte}

\section{I}

\section{La dinámica del capitalismo periférico}

He creído conveniente iniciar este nuevo trabajo -última etapa de la difícil tarea que me he propuesto- con un resumen de la interpretación del capitalismo periférico expuesta en trabajos anteriores. Me refiero siempre al capitalismo latinoamericano en su conjunto, prescindiendo de ciertas diferencias entre países que, si bien son importantes, no invalidan el significado primordial de aquella interpretación.

En este resumen he procurado responder a algunas críticas certeras dirigidas a la primera versión del presente trabajo, así como a mis escritos anteriores. ${ }^{1}$ Creo haber despejado de este modo el camino que nos permita discutir el esbozo de una teoría de la transformación.

\section{El fruto del progreso técnico y las fallas del sistema}

El capitalismo periférico es excluyente y conflictivo; dos grandes fallas que se acentúan por el carácter centrípeto del capitalismo desarrollado, la incongruencia de sus relaciones con la periferia y las consecuencias de su hegemonía.

El origen interno de esas fallas se encuentra en la forma de apropiación y distribución del fruto de la creciente productividad que trae consigo la penetración de la técnica de los centros en la heterogénea estructura social de la periferia, muy diferente de la de aquellos. En este proceso prevalece el juego de relaciones de poder.

Gran parte de ese fruto queda en los estratos superiores de la estructura en forma de excedente, gracias al poder que deriva de su concentración de los medios productivos.

Esta desigual distribución del ingreso en favor de los estratos superiores estimula en ellos la imitación

\footnotetext{
${ }^{1}$ Algunas de estas críticas y comentarios se publicarán en números próximos.

Dichas críticas y comentarios representan para mí una contribución muy esclarecedora, y expreso mi gratitud a sus autores. Además, y como siempre, Aníbal Pinto me ha favorecido con la agudeza de sus opiniones. Y Adolfo Gurrieri me ha prestado una colaboración paciente e inteligente, al discutir conmigo el desenvolvimiento de mis ideas con sugerencias muy positivas.
}

prematura de las formas de consumo de los centros, no exentas, por lo demás, de críticas profundas. La sociedad privilegiada de consumo que así se desenvuelve significa un considerable desperdicio del potencial de acumulación de capital, a lo cual se agrega la succión de ingresos por parte de los centros, especialmente por obra de las empresas transnacionales, gracias a su superioridad técnica y económica y a su poder hegemónico.

Esta insuficiente acumulación de capital, tanto en bienes físicos como en formación humana, y el crecimiento extraordinario de la población, explican fundamentalmente que el sistema no pueda absorber con intensidad los estratos inferiores de la estructura social. Tal es la tendencia excluyente del sistema.

Conforme la técnica va penetrando con amplitud en este último, sobrevienen mutaciones estructurales que se manifiestan en la formación de los estratos intermedios, tanto en la órbita del mercado como en la del Estado.

\section{Doble presión sobre el excedente}

En la órbita del mercado la gran masa de la fuerza de trabajo adquiere poder sindical y político con el avance del proceso de democratización, lo que le permite compartir el excedente, sea directamente o por medio de los servicios sociales del Estado.

A su vez, el Estado pugna por compartir el excedente para absorber una proporción cada vez mayor de la fuerza de trabajo, principalmente la de las clases medias tradicionales, que adquieren, como aquella otra, poder sindical y político. En este empleo de la fuerza de trabajo para ampliar los servicios del Estado, entre los cuales están los servicios sociales, suele darse una apreciable absorción espuria de gente innecesaria, por influjo de su poder político. El Estado capta una parte del excedente para responder a ello y a la adquisición de bienes y servicios en el mercado, en cumplimiento de sus funciones.

Esta doble presión, que desde la órbita del mercado y del Estado se ejerce sobre el excedente, va extendiendo la imitación del consumo de los centros a los estratos 
intermedios, aunque con mucha menor intensidad que en el caso de los estratos superiores.

La distribución del ingreso resulta así, fundamentalmente, de un juego cambiante de relaciones de poder, a medida que se operan las mutaciones de la estructura social al avanzar el progreso técnico.

\section{La clave dinámica del sistema}

Gracias al excedente y al capital que el sistema permite acumular para responder en gran parte al consumo de los estratos superiores, estos tienen en sus manos la clave dinámica del mismo. El sistema funciona regularmente mientras el excedente siga creciendo por sucesivos aumentos de productividad, a pesar de aquella doble presión de compartimiento.

No obedece este proceso a principio regulador alguno, de tal modo que si esa presión alcanza gran intensidad, comprime en tal forma el excedente que termina por resentirse la acumulación y también el desenvolvimiento de la sociedad privilegiada de consumo. Sobrevienen, entonces, los fenómenos conflictivos del sistema. En efecto, las empresas reaccionan elevando los precios para restablecer la dinámica del excedente, a lo cual sigue la contrarreacción de la fuerza de trabajo, con el alza consiguiente de remuneraciones, toda vez que tenga suficiente poder para hacerlo. Así comienza la espiral inflacionaria: nuevo tipo de inflación social que suele superponerse y agravar los efectos de otros factores.

Tal es el comienzo de la crisis del sistema en el curso avanzado del desarrollo, cuando el juego de relaciones de poder cobra gran impulso con el avance irrestricto del proceso de democratización.

La tendencia a este tipo de crisis no se manifiesta, desde luego, en países donde la estructura social no favorece la democratización o cuando las mutaciones de tal estructura llevan más bien a una democracia formal, privada en gran parte de sustancia.

\section{El excedente estructural}

Conviene recordar, ante todo, la significación estructural del excedente. Si el fruto del progreso técnico se concentra en los estratos superiores, es porque la mayor parte de los trabajadores que la acumulación de capital permite emplear no logra aumentar sus remuneraciones correlativamente a su creciente productividad. Esto se explica por la competencia regresiva de la fuerza de trabajo que permanece en capas técnicas de inferior productividad, o está desocupada. Solo se transfiere parte de este fruto de la técnica a una proporción limitada de la fuerza de trabajo que en los estratos bajos, sobre todo por su poder social, ha podido adquirir las calificaciones cada vez mayores exigidas por aquella.

El excedente no tiende a desaparecer por la competencia entre empresas, sino que se retiene, circula y se acrecienta debido a la expansión de la demanda que, dada la índole del proceso de producción y sus exigencias monetarias, precede a los productos finales. Tal expansión anticipada de la demanda impide que los precios desciendan con el aumento de productividad.

En la forma de apropiación del excedente radica la desigualdad social inherente al capitalismo periférico. No podría este funcionar sin aquella, pues la sociedad privilegiada de consumo -que es su manifestación saliente- tiene, como hemos visto, su peculiar dinámica. La imitación incesante de las formas de consumo de los centros y la correspondiente acumulación de capital solo pueden cumplirse gracias al crecimiento del excedente.

En efecto, si bien aquel doble compartimiento del excedente tiene efectos positivos en ciertas fases del desarrollo, termina por estrellarse frente a la resistencia de la sociedad privilegiada de consumo. Se inicia así la crisis, pues aquella se resiste a compartir el excedente más allá de cierto límite.

Es una dinámica que no admite correcciones superficiales. Antes bien, los graves problemas que plantea requieren otra dinámica sustancialmente diferente. Requieren la transformación del sistema.

¿Cómo se explica que no pueda avanzar el doble compartimiento del excedente y trasponer este límite crítico? ¿Por qué no podrían crecer los ingresos de la fuerza de trabajo a expensas del consumo privilegiado? La respuesta es categórica. No sería posible hacerlo sin detrimento de la dinámica del sistema; y esto es precisamente lo que sucede.

En efecto, si avanza el compartimiento del excedente más allá del límite crítico, no solo se comprime el consumo privilegiado, sino también la acumulación destinada en gran parte a satisfacerlo. Y no hay en el sistema mecanismo que compense el menoscabo de esta última. El doble compartimiento, tanto de la fuerza de trabajo en la órbita del mercado como del Estado, no va acompañado de un proceso de acumulación que reemplace al de los estratos favorecidos. En el mejor de los casos se trataría de una acumulación consuntiva, ya que no reproductiva. Se resiente pues la acumulación y también el crecimiento del excedente que surge de ella.

Nada está más lejos del designio de los estratos superiores de ingresos que transformar el sistema. $\mathrm{Su}$ 
reacción es otra: empeñarse en restablecer el crecimiento del excedente, dando comienzo a la espiral inflacionaria, que adquiere considerable impulso cuando se incorporan eventualmente los estratos inferiores a la pugna de compartimiento.

\section{Responsabilidad sindical y del Estado}

Suele ponerse el acento en la responsabilidad sindical cuando comienza y se desenvuelve la crisis del sistema. Pero la responsabilidad del Estado es también muy importante, y a veces predominante, cuando aumenta su compartimiento del excedente sin sentido de economicidad. Ello se debe no solamente a la presión política de la fuerza de trabajo para lograr ventajas sociales, sino también a la dinámica propia del Estado que le lleva a ampliar incesantemente sus servicios y su absorción de personal (incluidos los gastos militares).

Va perdiendo eficacia la ortodoxia fiscal conforme adquieren intensidad esas formas de compartimiento en la órbita del Estado. En verdad, aunque se cubra con impuestos el crecimiento exagerado de los gastos, al aproximarse el límite crítico del sistema, y más aún, si ya se ha traspuesto este límite, tales impuestos se vuelven en gran parte inflacionarios cuando recaen de un modo u otro sobre la fuerza de trabajo y esta tiene suficiente poder para resarcirse con el aumento de remuneraciones.

Todavía perduran ideas aplicables a fenómenos pretéritos. En las primeras fases del desarrollo no existe, o es muy débil, el poder sindical; y la fuerza de trabajo carece de capacidad para defenderse de la carga fiscal que sobre ella recae. En tales condiciones, el poder político dominante de los estratos superiores les permite eludir en gran parte su propio esfuerzo fiscal en salvaguardia del excedente.

Los impuestos no son inflacionarios en este caso. Y si ocurre entonces la inflación, es porque no se acude a ellos para cubrir el exceso de gastos. Son muy claras las reglas del juego en estas circunstancias: aumentar los impuestos en la medida en que los gastos no pueden comprimirse. Es la edad de oro de la ortodoxia fiscal y también monetaria.

\section{El empleo de la fuerza}

La apropiación privada del excedente es arbitraria. También lo es la pugna de compartimiento. Más comparten quienes tienen mayor poder, y esta arbitrariedad se agrava en el curso de la espiral inflacionaria. El empeño de restablecer la dinámica del excedente mediante el alza de los precios se vuelve ilusorio, por lo mismo que sobreviene en seguida la contrarreacción de la fuerza de trabajo. Sufre pues la acumulación y el surgimiento de nuevos excedentes, esto es, la materia redistribuible. Y al ocurrir estas consecuencias se debilita la capacidad del sistema para absorber el crecimiento de la fuerza de trabajo y la que vegeta en las capas inferiores de productividad.

El poder político de los estratos superiores, que parecía ir declinando con el avance democrático, irrumpe nuevamente y sobreviene el empleo de la fuerza, que permite quebrar el poder sindical y político de los estratos desfavorecidos, a fin de lograr el restablecimiento de la dinámica del excedente.

Recuérdese lo que ya he afirmado en otro escrito ${ }^{2}$ acerca del aumento de productividad gracias a la generosa explotación de ciertos recursos naturales agotables. En tal caso, el excedente puede seguir creciendo, sin trastornos, a pesar de la intensidad de la doble presión del compartimiento. Se posterga pues la crisis del sistema, pero no indefinidamente.

Cabe insistir que cuando predomina el poder de los estratos superiores en la estructura social, el poder sindical y político de la fuerza de trabajo no existe o es insuficiente, y el gasto del Estado se mantiene dentro de límites moderados, las crisis del desarrollo son de otra índole.

En el curso avanzado del desarrollo, si quienes detentan el poder militar en sus manos no se encuentran necesariamente bajo el dominio del poder económico y político de los estratos superiores, cabe preguntarse por qué intervienen para servir a la sociedad privilegiada de consumo. Hay por cierto un juego complejo de factores. Pero la explicación fundamental radica, a mi juicio, en que, dada la índole del sistema, no se dispone de otros criterios para restablecer su funcionamiento. Pues como ya se dijo, los estratos superiores tienen en sus manos la clave dinámica de aquel, esto es la capacidad de acumular capital, sin la cual no podría darse impulso al desarrollo. Se impone pues dejarles hacer, si bien con un ingente costo social, además del costo político.

En efecto, los ingresos de la fuerza de trabajo no solo tienen que comprimirse para alentar la acumulación, sino también para que puedan cubrirse en forma no inflacionaria aquellas extralimitaciones en la órbita del Estado, en la medida en que no resultare viable corregirlas. Tal es la aberración del sistema.

\footnotetext{
2 "Biosfera y Desarrollo", informe presentado al Seminario sobre Estilos de Desarrollo y Medio Ambiente, CEPAL/PNuma, Santiago, noviembre de 1979.
} 
No está de más insistir aquí en lo que ya he subrayado en trabajos anteriores. El sistema tiende a la crisis cuando, con el impulso del proceso de democratización, se fortalece el poder de la fuerza de trabajo, a la par que se acrecientan las funciones del Estado. En otros términos, cuando la doble presión del compartimiento del excedente se vuelve cada vez más intensa.

\section{Los economistas frente al desenlace del sistema}

Es realmente trágica la situación de aquellos economistas con sentido de equidad social que participan en la responsabilidad de una política semejante con los nuevos actores políticos que surgen con el empleo de la fuerza. Tienen que resignarse a adoptar las reglas pretéritas de la ortodoxia monetaria y fiscal, pues no disponen de otras a su alcance.

Digo economistas con sentido social, pues los hay también quienes, en plena euforia neoclásica, están persuadidos de la necesidad de sacrificar a la fuerza de trabajo por no haber sabido respetar las leyes del mercado. Hay que restablecer su libre juego suprimiendo lisa y llanamente su poder, y esto ¡no sin cierta fruición punitiva! Solo que se restablece también, por añadidura, el poder de los estratos superiores de captar y acrecentar el excedente.

No quisiera omitir aquí a ciertos economistas que se apartan prudentemente de tan desconcertante escenario. Unos a la espera de que el restablecimiento institucional, que algún día vendrá, les permita acaso recomendar medidas redistributivas concordantes con sus ideologías, o tal vez una política monetaria y fiscal libre de ataduras dogmáticas. Con lo cual se exponen a las vicisitudes de un nuevo ciclo político y una nueva frustración.

Otros, en cambio, esperan su momento para transformar el sistema. Solo que la transformación que preconizan no es la que me propongo exponer aquí.

\section{Falta de una nueva opción}

Sobreviene el empleo de la fuerza porque solo parece existir otra opción a la preconizada por los economistas neoclásicos: la de transferir al Estado la propiedad y gestión de los medios productivos, opción que se asienta, en última instancia, en un régimen político fundamentalmente distinto del liberalismo democrático. En ambos casos se recurre al autoritarismo. En uno, a un autoritarismo coyuntural que consagra la inequidad social del sistema; y en otro, a un autoritarismo estructural inspirado en un concepto de equidad social.
No parece existir otra opción que combine este concepto de equidad social con el vigor del desarrollo, la participación popular y el avance y consolidación del proceso democrático.

\section{La opción neoclásica}

El empleo de la fuerza hace posible seguir algunos principios neoclásicos, aunque convenientemente aderezados para responder a intereses dominantes, y no siempre aplicados con destreza.

Más aún, bajo el signo de esos principios, se adoptan medidas muy diferentes según los países y la aptitud de quienes las toman, tanto en lo que respecta al desarrollo interno como a las relaciones con los centros. Y los resultados son muy diversos, tanto en lo que atañe a la intensidad del desarrollo como a las relaciones con los centros. Pero sobre esta diversidad prevalece un común denominador: el agravamiento de la desigualdad social.

El razonamiento neoclásico, como es bien sabido, se basa en el juego regulador del interés personal en un régimen de libre competencia. Conviene recordarlo. Movidos los propietarios de los medios productivos por el poderoso resorte del interés personal, eligen en su actividad económica las técnicas e inversiones de capital de mayor productividad y más elevada ganancia. Pero el juego de la competencia va reduciendo la ganancia hasta eliminarla y solo queda la remuneración empresarial de aquellos. La conclusión es muy clara. Toda la colectividad se beneficia si se deja libre el juego de las fuerzas del sistema.

En nuestros trabajos precedentes hemos procurado demostrar que no es así, pues lejos de tender el sistema a la eliminación de la ganancia, esta se acrecienta y se retiene incesantemente en manos de los propietarios en forma de excedente, dando ímpetu a la sociedad privilegiada de consumo. Este fenómeno estructural del excedente ha sido ignorado por los economistas neoclásicos. Y por ello, sobre todo, sus razonamientos se alejan irremisiblemente de la realidad periférica.

Asimismo, los hechos niegan palmariamente la tendencia espontánea al pleno y eficaz aprovechamiento de los recursos productivos. No advierten tales economistas el desperdicio del potencial de acumulación; ni tampoco el desperdicio de la fuerza de trabajo, principalmente en los estratos inferiores de la estructura social. Y frente al enorme daño que sufre la biosfera con el pleno juego de las leyes del mercado, lo atribuyen a fenómenos exógenos que nada tienen que ver con la virtud de sus principios. 
¿Dónde se encuentra aquella 'mano invisible' que asignaría sabiamente esos recursos productivos difundiendo equitativamente los frutos del desarrollo?

\section{Liberalismo económico y liberalismo político}

Que no funciona así el capitalismo periférico, hemos tratado de demostrarlo en reiteradas oportunidades. Promueve la concentración del poder económico y la inequidad distributiva. Y la concentración del poder económico trae consigo la del poder político de los estratos favorecidos.

Es cierto que en el proceso de democratización el poder de compartimiento que va adquiriendo la fuerza de trabajo se contrapone al poder de aquellos, así como la gravitación del Estado. Pero en el desenlace de la crisis se termina por acudir al empleo de la fuerza. Sobreviene así la quiebra del liberalismo democrático, mientras florecen las ideas del liberalismo económico, un liberalismo falseado que, lejos de traer la difusión de los frutos del desarrollo, consolida flagrantemente la inequidad social.

Es evidente que no se ha logrado aún en la periferia latinoamericana asentar sólidamente el liberalismo de- mocrático; bien conocemos sus vicisitudes, sus avances promisorios y penosos retrocesos. Pero el pasado no sabría explicarlo todo. Aparecen nuevos y complejos elementos a medida que se operan las mutaciones de la estructura social por obra de la técnica. Y el empleo de la fuerza adquiere una significación distinta de la que poseía en otros tiempos: acarrea ese divorcio absoluto entre el liberalismo democrático y el liberalismo económico.

¿Cuál es el concepto esencial del liberalismo democrático? Impedir la concentración arbitraria del poder político en desmedro de las libertades y derechos de los individuos y de su participación social y política. A su vez el liberalismo económico significa distribuir a toda la colectividad los frutos del desarrollo y difundir así el poder económico, en plena concordancia con aquellos objetivos políticos del liberalismo democrático. Ambos surgieron de una vertiente filosófica común y a pesar de ello se vuelven contradictorios en el capitalismo periférico. El empleo de la fuerza permite restablecer el liberalismo económico -según la opción neoclásica-, sacrificando inexorablemente al liberalismo político. Y ambos liberalismos naufragan en aquella otra opción en que se transfiere al Estado la gestión de la economía.

\section{II}

\section{Esbozo de la transformación}

\section{Una síntesis de socialismo y liberalismo}

$\mathrm{Al}$ iniciar este esbozo debo decir clara y distintamente a dónde me propongo llegar. Estoy buscando una síntesis entre socialismo y liberalismo o, si se quiere, una versión del socialismo basada en la libertad del individuo y en nuevas formas de convivencia social.

Socialismo, en cuanto el Estado tendrá que cumplir una responsabilidad fundamental, además de otras: la responsabilidad de decidir democráticamente cómo ha de emplearse socialmente el excedente a fin de acumular con mucho más intensidad y distribuir equitativamente los frutos del progreso técnico.

Y liberalismo, en cuanto el cumplimiento de esa responsabilidad tiene que ser compatible con el ejercicio de la libertad económica, tanto por lo que significa en sí misma como por ser esencial a la libertad política y a los derechos humanos que le son inherentes.
Esta síntesis entre socialismo y liberalismo es la nueva opción que en estas páginas me propongo explorar.

Al hacerlo quiero manifestar expresamente que no me inspiro en las corrientes de la socialdemocracia de Europa Occidental, donde esclarecidos latinoamericanos creen encontrar la solución de nuestros problemas.

En verdad, se ha conseguido allí la utopía de difundir los frutos del desarrollo a muy amplias capas de la población. Ya no se trata de un asunto de acumulación -en gran parte resuelto por ellos tras un largo proceso-, sino de seguir avanzando y llegar progresivamente a nuevas formas de gestión y participación social.

En la periferia necesitamos resolver, a la vez, los problemas de acumulación y distribución. Y no podríamos invocar, como en aquellas latitudes, la así llamada economía social de mercado, porque la estructura social que está detrás del mercado en la periferia 
latinoamericana es fundamentalmente diferente de la de los países que alcanzaron un alto grado de desarrollo.

En el otro extremo del socialismo europeo encuéntrase el marxismo-leninismo. En la Unión Soviética se ha cumplido un esfuerzo ingente y deliberado de acumulación y equidad distributiva. Las exigencias de esa doctrina, las condiciones históricas en que se ha iniciado este gran experimento social y la constelación adversa de fuerzas internacionales en que ha tenido que desenvolverse, han contribuido allí, junto a consideraciones ideológicas, a estructurar un régimen donde la propiedad de los medios productivos y su gestión por parte del Estado tienen consecuencias que no se concilian con las aspiraciones del liberalismo democrático y sus valores inherentes, y tiene esto para mí una significación definitiva. Me aparto de este sistema -por mucho que respete lo conseguido- por consideraciones políticas además de otras de índole económica.

Me explayaré más adelante sobre las razones de mucho peso que tengo para pensar así. Debo expresar aquí un juicio valorativo de carácter irrenunciable. No basta que un sistema permita la equidad social y el vigor del desarrollo; tiene asimismo que ser compatible con la vigencia de ciertos principios que se han ido cristalizando en el curso accidentado del liberalismo democrático. Es una herencia que hemos recibido de la civilización occidental, cuya plena significación nunca se siente y comprende mejor que cuando tales principios se vulneran y eclipsan.

Escapemos pues a una dependencia intelectual que entorpece la visión de los problemas nuestros. Ello exige hacer bien explícitos nuestros objetivos y, sobre todo, subrayar clara y distintamente los valores que los inspiran.

El objetivo social es evidente. Son muy graves las disparidades distributivas de carácter estructural en el capitalismo periférico y hay que corregirlas mediante el uso social del excedente. Tal es el objetivo de equidad, que no podría lograrse persistentemente sin un más alto ritmo de acumulación de capital, no solo en bienes físicos, sino en formación humana.

Esto último reviste gran importancia, pues además de esas desigualdades estructurales hay otras de carácter funcional que provienen de las diferencias de capacidad en los individuos para hacer frente a las exigencias de la técnica, cada vez más complejas. En la adquisición de esas capacidades gravita fuertemente el poder social inherente a la posición de aquellos en la estructura de la sociedad. Y la corrección de las disparidades estructurales sería muy incompleta si, gracias a un esfuerzo intenso de formación humana, no se disolvieran progresivamente las grandes diferencias de poder social. No podrían justificarse de otro modo las desigualdades funcionales.

La distribución del ingreso tiene que ser dinámica para que sea perdurable; requiere, pues, un vigoroso desarrollo. Si en los centros se ha dado en pensar en una posible detención del impulso dinámico, muy lejos estamos aún en la periferia de haber llegado a condiciones que hagan posible entrar en una fase semejante. Decididamente, debe acelerarse el ritmo de crecimiento del producto, pero no con la misma composición, sino con otra que responda a requerimientos de equidad social. Y también a las exigencias de la biosfera.

Este empeño de crecer más intensamente nos plantea una disyuntiva cuya importantísima significación no podría soslayarse. Nos hemos referido de pasada a ello. ¿Será posible transferir la propiedad y gestión de los medios productivos al Estado para conseguir el uso social del excedente sin desmedro de la libertad personal?

Parte integrante e inseparable de la libertad personal es la libertad económica. Aquí encontramos un juicio valorativo cuyo alcance es preciso definir. Cuando en ejercicio de esa libertad económica el afán de consumir adquiere proporciones exageradas, es fatal que termine erosionando otros valores humanos. ¿Habría que reprimir esa tendencia? ¿Sería obra del Estado omnipotente y omnisciente? La solución tiene que brotar de aquellos derechos esenciales del individuo y de su convivencia social. Persuasión y no coerción. Pero una persuasión de signo muy diferente a la que despliegan los formidables intereses que impulsan la sociedad de consumo.

Persuasión y participación creadora, desde la escuela hasta los medios masivos de información y difusión social.

¿Por qué no emplear esos medios para elaborar y propagar valores humanos que el consumo conspicuo está sofocando? ¿Por qué no habrán de surgir nuevas motivaciones que frenen la penetración del interés económico más allá de lo que exige la eficacia económica del sistema?

Trátase de valores humanos de carácter trascendente. No sabríamos discurrir ahora acerca de ellos. Habrá quienes sepan hacerlo mejor que nosotros en el ancho suelo de América Latina. Pero la transformación deberá crear las condiciones propicias al surgimiento y fructificación de tales valores. Y también a la recuperación de ciertos principios éticos que naufragan en el juego del mercado.

Son principios esenciales a la cohesión social, sin la cual el nuevo sistema quedaría expuesto a una 
inestabilidad desintegradora. Y esos principios no podrían imponerse por la coacción del Estado.

\section{El uso social del excedente}

Ya se ha visto en el lugar pertinente que el uso privado del excedente carece de racionalidad colectiva y es, en última instancia, el origen de grandes fallas en el sistema. Su racionalidad responde primordialmente al ámbito limitado de la sociedad privilegiada de consumo.

En consecuencia, el Estado tiene que determinar en qué forma deberá emplearse el excedente para cumplir los objetivos económicos y sociales de la transformación. Para satisfacer estos objetivos se impone elevar con la mayor intensidad posible el ritmo de acumulación de capital, para ocupar con creciente productividad el incremento de la fuerza de trabajo, así como la que se encuentra en los estratos inferiores y aquella que, principalmente en los estratos intermedios, el sistema absorbe espuriamente, debido en gran parte a su insuficiente acumulación.

El uso social del excedente permitirá imprimir al nuevo sistema una dinámica fundamentalmente diferente de la que caracteriza al capitalismo periférico.

Explicaré a continuación en qué consiste el uso social del excedente, a través de una presentación más bien esquemática, pues me limitaré a exponer mis ideas en líneas generales para facilitar su análisis crítico. Por consiguiente, no me propongo entrar en aspectos que, si bien son importantes, distraerían la atención de lo que considero primordial. Espero tener, de todos modos, la oportunidad de hacerlo en algún otro trabajo.

El uso social del excedente responde a la necesidad de establecer por parte del Estado una disciplina impersonal y colectiva de acumulación y distribución compatible con el ejercicio de la libertad económica en el juego del mercado.

En esa disciplina de acumulación todas las empresas debieran acrecentar la cuantía del excedente que se dedica a la acumulación a expensas del consumo de los propietarios de los medios productivos.

Además, tendrían también que acrecentar su acumulación a expensas del consumo quienes desempeñan responsabilidades ejecutivas y el personal de las empresas que, debido a sus calificaciones, comparte espontáneamente una parte del excedente en los estratos superiores y la franja más alta de los estratos intermedios.

Si bien todas las empresas deberían acrecentar su acumulación, solamente tendrían responsabilidades redistributivas aquellas que derivan la mayor parte del excedente por concentrar una fuerte proporción de los medios productivos. En consecuencia, las empresas medianas y pequeñas solo tendrían responsabilidad de acumular.

Una parte del excedente de las grandes empresas se redistribuiría no solamente a su fuerza de trabajo, sino a la que se desempeña en el conjunto de las empresas. De esta manera se irían corrigiendo paulatinamente las disparidades distributivas de carácter estructural. Y así podría acrecentarse el consumo privado y social de la fuerza de trabajo, a expensas del consumo de los estratos privilegiados.

La pugna distributiva que ahora trastorna el funcionamiento del sistema habría sido sustituida entonces por una disciplina inspirada en consideraciones de equidad social compatibles con la eficiencia económica del nuevo sistema.

Solamente subsistirían las diferencias de remuneraciones de carácter funcional. Conforme aumenten su capacidad, experiencia y calificaciones, los individuos irían elevándose por sobre el conjunto en la escala de responsabilidades y remuneraciones. Esta indispensable movilidad social requiere formas adecuadas de formación para ir disolviendo las diferencias de poder social.

Además de esta forma de estímulo a la productividad individual, se conciben otras concernientes a todo el personal de cada empresa y en relación al crecimiento de su excedente.

\section{Propiedad y acumulación de capital}

Corresponde ahora discurrir acerca de la propiedad del capital que se va acrecentando con la acumulación del excedente. Conviene antes recordar que los grandes males del sistema no provienen de la propiedad en sí misma, sino de la apropiación privada del excedente y la concentración que trae consigo. Hay tres formas, y diferentes combinaciones entre ellas:

- la difusión del nuevo capital en la fuerza de trabajo;

- la mayor acumulación en manos de quienes tienen los medios productivos;

- la acumulación por el Estado.

La primera forma significa dar a la fuerza de trabajo una creciente participación en la responsabilidad, de acumular. Esta creciente acumulación de capital por parte de la fuerza de trabajo iría abriendo paso a su gestión en las grandes empresas, las que así llegarían a convertirse en empresas de gestión autónoma cuando su participación fuera mayoritaria.

La segunda forma, concerniente a la acumulación obligatoria por los mismos propietarios actuales de 
los medios productivos, daría a estos un mayor interés en el funcionamiento de las empresas que en el caso precedente, pero también se reforzaría la concentración del capital en los estratos superiores. Sin embargo, al desaparecer los propietarios, el capital acumulado podría redistribuirse en parte a la fuerza de trabajo, y se iniciaría de este modo la redistribución de sucesivos excedentes. En tal caso las empresas también se convertirían en empresas de gestión autónoma, si bien al cabo de un tiempo más prolongado que en el caso anterior. Ahora bien, en todo ello tienen gran importancia consideraciones de índole pragmática.

Veamos ahora la tercera forma de acumulación en que el nuevo capital pasaría a ser del Estado. No se trataría de la socialización de todas las empresas, sino de las grandes empresas. Se contrarrestaría de esta manera la tendencia hacia la concentración privada y los hombres que se encuentran en la cúspide del Estado, si bien lograrían adquirir de esta manera un considerable poder político, este no sería incontrastable como en el caso de la socialización total, punto este sobre el cual volveremos en el lugar pertinente.

Más aún, esta socialización parcial sería compatible con una efectiva pluralidad política, a diferencia de la socialización general. Sin embargo, la contienda de partidos podría tener muy serias consecuencias sobre la vida de las empresas. No se trata de imaginar estas consecuencias, sino de comprobar aquello que, con ciertas excepciones, ocurre en nuestros países. La elección de dirigentes de las empresas del Estado no se efectúa generalmente con criterios de eficiencia, sino por interés político. Y este hecho, además de la absorción espuria de personal, menoscaba el excedente; más aún, este a veces se destruye o se transforma en pérdidas.

Es evidente que estas consecuencias adversas podrían atenuarse, si no evitarse, toda vez que se decidiera la participación del personal en la gestión de las empresas del Estado. Se trataría pues de un régimen donde habría ciertos elementos que atañen a la empresa autónoma.

Conviene examinar ahora otra faceta importante de la acumulación cuando esta la realiza la fuerza de trabajo. Los recursos provenientes del excedente que se dedicasen a tal propósito quedarían en gran parte en las mismas empresas de donde surgen, para hacer frente a su expansión o a la formación de nuevas empresas; el Estado, con el remanente, promovería también la formación de nuevas empresas, o apoyaría la expansión o el mejoramiento de ciertas empresas existentes, especialmente las medianas y las pequeñas.
Cabe reiterar que la distribución del capital a la fuerza de trabajo no se efectuaría por empresa, según la acumulación que a cada una correspondiere, sino al personal del conjunto de las empresas y de acuerdo con normas impersonales.

Además de esta participación en el capital, el incentivo para el buen funcionamiento aconsejaría distribuir al personal de cada empresa una proporción del excedente que sobrepasara ciertos límites.

\section{Complicaciones de la distribución}

El uso social del excedente es apenas el punto de partida de muy difíciles problemas de distribución. Para comprender la índole de esos problemas debe tenerse presente la composición heterogénea de la fuerza de trabajo y las relaciones de poder que ella genera, contrariamente a lo que suele suponerse en algunos razonamientos inspirados en la errónea noción de dualidad social.

A los fines de nuestra exposición conviene distinguir, en forma esquemática, los siguientes grupos estructurales, según el examen de trabajos anteriores. ${ }^{3}$

- la fuerza de trabajo que, en gran parte por su poder social y también por su experiencia, posee las calificaciones crecientes exigidas por la penetración de la técnica. Se encuentra principalmente en los estratos superiores y también en los tramos más altos de los estratos intermedios, y comparte en forma espontánea el aumento del excedente sin necesidad de poder sindical; si bien suele recurrir a ciertas combinaciones para elevar los ingresos a veces con extraordinaria intensidad;

- la extensa gama de la fuerza de trabajo de los estratos intermedios que, no obstante tener calificaciones, si bien inferiores a las otras y de fácil adquisición, necesita poder sindical y político para compartir el excedente en el sistema vigente.

Esta fuerza de trabajo en los estratos intermedios se desenvuelve tanto en la órbita del mercado como en la del Estado. Y los intereses de ambas órbitas a veces son coincidentes y otras divergentes, según diferencias en el poder sindical y político:

- la fuerza de trabajo en los estratos inferiores, con escaso o nulo poder redistributivo, y

- el incremento de la fuerza de trabajo.

\footnotetext{
${ }^{3}$ No pretendo por ahora examinar detalladamente la estructura y la gran diversidad de intereses que en ella se mueven. Me he limitado a mencionar los grupos sociales que tienen gran importancia en las relaciones de poder $\mathrm{y}$, por tanto, en el juego distributivo.
} 
El aumento del ritmo de acumulación de capital, no está de más recordarlo, es necesario sobre todo para absorber con creciente productividad la fuerza de trabajo de los estratos inferiores y el personal, principalmente de los estratos intermedios, empleado espuriamente en el Estado, así como el incremento de la fuerza de trabajo. De ello depende fundamentalmente la eficacia social del nuevo sistema.

Esta mayor acumulación plantea muy serios problemas. Hemos señalado ya que el excedente tiene que redistribuirse a la fuerza de trabajo y que una parte se haría bajo la forma de nuevo capital.

No habría razones, obviamente, para incluir en la redistribución a los estratos superiores de la fuerza de trabajo y también a los tramos más altos de los estratos intermedios que ahora participan espontáneamente del fruto de la creciente productividad. Más aún, la responsabilidad de acumular, que recae también sobre ellos, debiera cumplirse a expensas de su propio consumo.

Por el contrario, la acumulación del resto de los estratos intermedios, a medida que se benefician con la distribución del excedente, se haría sin comprimir su consumo anterior, que más bien mejoraría en medida compatible con las exigencias de acumulación.

A los estratos inferiores no cabría extender estas exigencias de acumulación: en ellos las consideraciones de consumo inmediato podrían prevalecer sobre la necesidad de acumular. Compréndese fácilmente la justificación de esto último. La distribución dinámica del ingreso es un proceso que necesita un tiempo más o menos prolongado para cumplirse, por lo cual habría que responder en cierta medida a la presión inmediata del consumo privado y social de tales estratos inferiores.

Después de lo que acaba de decirse, se hace evidente que la transformación podría frustrarse en gran parte si la presión del consumo no permitiera responder a las exigencias de racionalidad colectiva, tanto en lo que atañe al acrecentamiento de capital como a su composición social.

\section{Los incentivos}

Y también podría frustrarse hasta comprometer seriamente la dinámica del nuevo sistema si esa presión del consumo llegara a menoscabar la eficiencia económica del sistema. Las consideraciones de eficiencia social no podrían exagerarse en detrimento de aquella otra. Aquí llegamos al punto de los incentivos que ya hemos mencionado. La penetración de la técnica requiere calificaciones cada vez mayores en la fuerza de trabajo, desde las más elevadas hasta las más modestas. Se necesitan incentivos -y también oportunidades- para adquirir tales calificaciones y utilizarlas plenamente en la actividad económica.

Suele haber una lamentable confusión acerca de los incentivos que conviene disipar. El aumento de la productividad es el resultado de la combinación de dos elementos, a saber: las innovaciones técnicas que se cristalizan en los bienes de capital, por decirlo de alguna manera; y las calificaciones exigidas por el progreso técnico. Pues bien, la participación en el fruto de esa creciente productividad por parte de quienes disponen de tales calificaciones, incluso las de índole empresarial, constituye un incentivo indispensable a la dinámica de cualquier sistema, si bien en el capitalismo periférico suele ser exagerado.

Distinto es el caso del excedente; o sea, la parte de aquel fruto que no se traslada espontáneamente a la fuerza de trabajo debido a la heterogeneidad de la estructura social. Podría pensarse que su captación por los propietarios de los medios productivos constituye un incentivo indispensable para acrecentar la acumulación de capital y obtener así nuevos incrementos de productividad.

Si el excedente se empleara a fondo de esta manera, podría haber una cierta justificación pragmática de su apropiación privada. Pero no sucede así, debido a un incentivo contrario: el incentivo a consumir imitando las formas de existencia de los centros.

Tiene pues que acudirse al uso social del excedente para resolver el problema de la acumulación. Pero ¿cómo distinguir qué parte del fruto corresponde a la actividad empresarial de los propietarios de los medios productivos y qué parte corresponde al excedente propiamente dicho?

Los neoclásicos habían llegado a despejar esta incógnita con gran elegancia conceptual: en el punto de equilibrio del sistema se extingue la ganancia y solamente queda la remuneración empresarial; desaparece pues el excedente.

Pero no es así, puesto que las ganancias lejos de desaparecer van formando y acrecentando el excedente global. En consecuencia, el problema solo tiene una solución empírica. Es cierto que en las empresas parecerían distinguirse claramente las remuneraciones de lo que es ganancia. Sin embargo estas remuneraciones, sobre todo en los estratos superiores y en los tramos más altos de los estratos intermedios, están influidas por el excedente y solo sería posible separar estos dos elementos en forma empírica.

En pocas palabras, la dinámica del nuevo sistema requiere, por un lado, incentivos a la productividad y, 
por otro, la necesidad de acumular como condición ineludible de la redistribución del excedente a la fuerza de trabajo.

Tampoco podría olvidarse, desde otro punto de vista, que en las calificaciones requeridas por la penetración de la técnica hay, en general, un fuerte contenido de poder social. La solución no está en menoscabar a quienes disponen de ellas (o combatirlos políticamente), sino en eliminar en forma progresiva ese poder social, brindando a todos, en especial a quienes vegetan en los estratos inferiores, adecuadas oportunidades de formación y movilidad social.

Conviene volver a subrayar este asunto de tanta significación. La redistribución del ingreso irá eliminando las disparidades sociales de carácter estructural; pero seguirán presentándose disparidades funcionales. El problema consiste en eliminar el elemento residual de privilegio contenido en estas últimas, antes que sofocar arbitrariamente los incentivos.

Espero que todo esto resulte claro y sencillo. Pero por mucho que así fuere, cabe reconocer las dificultades de una redistribución equitativa y dinámica a la vez, debido al juego de intereses inmediatos. Y digo inmediatos porque hay una indudable convergencia de intereses de largo aliento. Convergencia que solo podría conseguirse después de un período más o menos largo de transición; pero es esta transición, precisamente, lo que interesa examinar. No queda el socorrido recurso de los economistas neoclásicos -y también keynesianos- de pasar de una posición de equilibrio del sistema a otra sin advertir los cambios que ocurren entre ambas posiciones.

\section{El Estado y las relaciones de poder}

$\mathrm{Al}$ examinar el funcionamiento del presente sistema dijimos que los estratos superiores que concentran la mayor parte de los medios productivos tenían en sus manos la clave dinámica de aquel. En el nuevo sistema esta clave pasará al Estado, gracias a su responsabilidad primordial en el uso social del excedente. Asimismo, expresamos que para cumplir esta responsabilidad el Estado no necesita tomar la propiedad de aquellos medios productivos, sino determinar cómo ha de emplearse el excedente para cumplir los objetivos de la transformación. ¿Pero qué Estado? ¿Cómo va a sobreponerse el Estado al juego de relaciones de poder si su funcionamiento es, en gran parte, consecuencia de tales relaciones, además de la dinámica misma del Estado?

Mientras las relaciones de poder permitan mantener el poder dinámico del excedente -basado en la inequidad social-, no se concibe con facilidad que quienes se apropian primariamente del excedente estén dispuestos a cederlo mediante un consenso democrático. Pero cuando sobreviene la crisis del sistema, su dislocación económica y su desintegración social, el poder democrático de los estratos intermedios e inferiores podría sobreponerse al poder de los estratos superiores, traspasando al Estado esa clave dinámica del sistema. Opción que también podría presentarse a quienes emplean la fuerza para conjurar los trastornos: en tal caso se emplearía para transformar el sistema en vez de sostenerlo. Y si no fuera así, quedaría siempre abierta esta opción cuando las circunstancias permitan volver a la normalidad institucional. Sin embargo, esta normalidad quedaría expuesta a una nueva crisis si no se sustentara en la transformación del sistema y una transformación del mismo Estado.

Para la transformación se necesitan nuevas reglas de juego para guiar la acción de los hombres que tienen la responsabilidad de ejecutar las decisiones democráticas sobre el uso social del excedente. Son hombres políticos y están movidos también por sus intereses políticos inmediatos. Su poder no podría ser discrecional; tiene que ejercerse dentro de ciertas reglas de juego que respondan a los objetivos económicos y políticos de la transformación. ${ }^{4}$

\section{Planificación del excedente y mecanismos institucionales}

Las nuevas y complejas funciones que así adquiere el Estado van a requerir importantes transformaciones en sus mecanismos institucionales. Se trata de una intervención suprema a fin de conseguir lo que no es dable lograr mediante el funcionamiento del mercado, una intervención muy diferente de la serie numerosa de intervenciones en que incurre el Estado, muchas de ellas provocadas por no haber tenido en sus manos los resortes superiores que determinen la manera en que deberá emplearse el excedente.

\footnotetext{
${ }^{4}$ Vienen a propósito aquí las viejas reglas del funcionamiento monetario. Significaban dar un poder considerable a la autoridad monetaria, pero dentro de normas establecidas institucionalmente por el órgano político del sistema. Y quienes tenían la responsabilidad ejecutiva en el órgano político tenían también que limitar su influencia sobre la autoridad monetaria. Este sistema regulador pudo funcionar en general con eficacia mientras el poder de los estratos superiores permitía manejar sin mayores trastornos la clave dinámica del sistema. No así cuando los estratos intermedios y los inferiores adquieren un gran poder de compartimiento del excedente. Las reglas del juego resultan entonces inoperantes o, lo que es peor, contraproducentes.
} 
A fin de responder a las exigencias de una racionalidad colectiva de que el sistema carece actualmente, el Estado deberá determinar cómo ha de repartirse el excedente entre acumulación, consumo y servicios del Estado. Bien sabemos que la incompatibilidad entre estos distintos fines se acentúa en las fases más avanzadas del sistema y conduce a su crisis.

Se impone por tanto compatibilizar, entre sí estos distintos fines. ¿Pero con qué criterios deberá proceder el Estado? ¿En qué medida deberá proponerse la elevación del ritmo de acumulación?

No vacilo en afirmar que de esto depende principalmente el éxito de la transformación, pues el ritmo de acumulación es esencial para la distribución dinámica del ingreso. Para ello debe acelerarse la absorción de los estratos inferiores, y la de la fuerza de trabajo de los estratos intermedios que se ha insertado espuriamente en el sistema, así como el incremento de la población.

¿Cuáles son las dimensiones de esta tarea de absorción de fuerza de trabajo? ¿Hasta dónde deberá elevarse el ritmo de acumulación para lograr este objetivo al cabo de un cierto período de tiempo?

He aquí preguntas de respuesta harto difícil, pues cuanto más se trate de elevar el ritmo tanto menos recursos podrían destinarse a mejorar prontamente el consumo privado y social de la fuerza de trabajo desfavorecida. Asunto este que atañe también, y en gran medida, a la magnitud del excedente que el Estado deberá tomar para acrecentar sus servicios.

El uso social del excedente exige comprimir el consumo de los estratos favorecidos para cumplir los fines que acabamos de mencionar; habría que tomar con tal propósito una parte importante del excedente y de los ingresos de aquellos. Problema este muy delicado pues hay que ponderar por un lado las necesidades de acumulación y distribución y, por el otro, el incentivo que requieren quienes tienen ahora la responsabilidad directiva y ejecutiva de las empresas, y quienes habrán de reemplazarlos en la marcha hacia la empresa social. Esto concierne especialmente a la distinción entre excedente y remuneraciones empresariales que, como llevamos dicho, tendrá que obedecer a consideraciones pragmáticas a falta de criterios certeros.

Y finalmente, una vez determinado el nuevo ritmo de acumulación: ¿cómo distribuir esta responsabilidad entre estratos superiores y el resto de la estructura social a medida que se redistribuye el excedente?

La más simple reflexión acerca de los aspectos que acaban de presentarse así como otros que por brevedad no abordamos, basta para abarcar las complejas tareas que ello va a exigir al Estado.
Estas tareas tendrán que desenvolverse en dos planos estrechamente vinculados: el plano técnico y el plano político. En el primero, deberá elaborarse el examen cuantitativo de los diferentes aspectos del uso social del excedente y presentarse diversas alternativas acerca de las formas de hacerlo para responder a los objetivos de la transformación; tarea esta cuyos resultados deberán pasar al plano político donde habrán de tomarse las decisiones correspondientes.

Recalco esto último, pues si las tareas en el plano técnico son de gran importancia hay que escapar a las seducciones de una tecnocracia autoritaria. Las decisiones fundamentales son políticas y no técnicas. Sin embargo, para tomarlas no podría prescindirse del trabajo de elaboración técnica, ni los hombres que tienen esas responsabilidades políticas podrían sobreponerse a la independencia de examen y la proposición de alternativas de quienes desempeñan responsabilidades técnicas.

De la combinación de tareas en ambos planos deberá surgir el plan de uso social del excedente. La planificación adquirirá de este modo un sentido del que carece actualmente, pues la apropiación privada del excedente conduce fatalmente a trastornos que impiden actuar deliberada y racionalmente sobre los factores del desarrollo.

Basta presentar aquí esta idea sin entrar prematuramente en detalles. Solo cabe agregar que la planificación del excedente tendrá que extenderse a una serie de años para conseguir una razonable estabilidad en el cumplimiento de sus objetivos. Estabilidad y no rigidez, puesto que, aparte de contingencias que obliguen a modificar la ejecución del plan, no sería posible congelar las relaciones de poder emergentes de los diferentes grupos sociales, relaciones donde se manifiestan los cambios que se van operando en la estructura social.

Tampoco ahondaremos en estos primeros esbozos la discusión de los mecanismos institucionales de que el Estado deberá valerse para cumplir sus responsabilidades en el uso social del excedente. Bástenos mencionar aquí los mecanismos relativos a esas tareas de planificación a las que acabamos de hacer referencia, a la participación consultiva de diferentes grupos sociales, a la toma de las decisiones políticas pertinentes, y a la supervisión de la ejecución del plan. Recuérdese, además, a la luz de los escritos de la CEPAL, que la planificación se impone para que el Estado, con sentido de previsión, determine ciertos cambios de gran importancia en la estructura productiva que se sustrae al funcionamiento del mercado, por más que se hubiese llegado a resolver el problema de acumulación y distribución. 
Desde otro punto de vista, el Estado deberá establecer las modalidades del uso social del excedente, tanto en lo que concierne a la acumulación, como a la participación en ella de la fuerza de trabajo, conforme se cumple la redistribución. Esas modalidades tienen que vincularse al régimen fiscal y las modificaciones que en él sería necesario introducir para hacer compatibles objetivos diferentes.

Como ya se ha dicho, una parte importante de la acumulación se haría en las mismas empresas, y otra parte en otras empresas o en empresas nuevas. Aquí el Estado cumplirá funciones de promoción de gran significado dinámico, para lo cual requiere, desde luego, un mecanismo que canalice recursos financieros y técnicos y promueva la investigación tecnológica.

Habría mucho que decir sobre estas y otras materias, pero ello significaría ir más allá del esbozo preliminar de la transformación al que debe limitarse este trabajo, Pero como reconocimiento a las críticas que se me han hecho en cuanto a la estructura productiva, cabrá discutir a su tiempo las medidas indispensables para corregir ciertas desviaciones en la acumulación y el consumo, ya sea modificando el sistema de precios o en otras formas impersonales.

Además, se presenta un amplio campo de discusión donde no podría entrar, tanto para no desbordar mi exposición como por ser materias que exceden mi competencia. Me refiero especialmente al régimen constitucional del excedente, esto es a los principios básicos que debieran presidir su uso social y los mecanismos institucionales necesarios, a las disposiciones legales relativas a estos últimos y a la gestión política del plan y sus eventuales modificaciones. También sería necesario establecer el régimen legal y la responsabilidad del Estado con respecto a las empresas donde debería acumularse una parte del excedente.

Estas reflexiones sobre el Estado llevan a una conclusión que conviene subrayar. Los cambios en las relaciones de poder, en la estructura del poder político, son condición indispensable, pero de ningún modo suficiente de la transformación del sistema. Es necesario saber para qué se transforma y cómo se transforma; en suma, es necesaria una teoría de la transformación.

A su vez, tampoco es suficiente construir esa teoría si no cambia la estructura del poder político.

Esa opción democrática se vislumbra, aunque no se ha formulado aún; debemos buscarla afanosamente. Espero que sea una síntesis entre socialismo y liberalismo, de un liberalismo inspirado en su vertiente filosófica primigenia.

\section{Las empresas en la transformación}

Tampoco entraremos en este punto, pero sí conviene mencionar los cambios que deberían ocurrir en las empresas como consecuencias del uso social del excedente. A la luz de lo expresado, cuando se discurría acerca de la acumulación y de lo que se dirá enseguida, habría las siguientes categorías de empresas:

- las empresas pequeñas donde la acumulación y la gestión quedarían en manos de sus propietarios;

- las empresas medianas donde parte de la acumulación comenzaría a realizarse gradualmente en favor del conjunto de la fuerza de trabajo, en tanto que la gestión de aquellas continuaría siendo responsabilidad de los propietarios;

- las empresas grandes y las que llegaran a serlo por el crecimiento de las medianas. En este caso la progresiva acumulación en manos de la fuerza de trabajo abriría el paso a la gestión autónoma del personal;

- las empresas cuyo capital sería del Estado;

- las empresas extranjeras.

Cabe detenerse brevemente acerca de la significación de esta pluralidad empresarial.

No ha de sorprender el tratamiento especial de las empresas pequeñas y medianas si se recuerda lo que se lleva dicho sobre la significación de la propiedad de los medios productivos. Lo que importa fundamentalmente es evitar su concentración, pues de ella surge la concentración del excedente y, a su vez, un nuevo proceso de concentración del capital. Esto se conseguirá con la difusión social de este último en el conjunto de la fuerza de trabajo de todas las empresas.

En cambio, desde el punto de vista de la dinámica del sistema y de los incentivos que han de moverlo, conviene que el capital de estas empresas medianas y pequeñas se acumule en la mayor medida posible en manos de sus propietarios. Debe recordarse, sin embargo, que comenzaría a distribuirse el excedente de tales empresas a la fuerza de trabajo a partir de cierto punto.

La importancia de la acumulación por parte del personal de las empresas va mucho más allá de una operación redistributiva. En efecto, la difusión del nuevo capital iría acrecentando la proporción de la propiedad de los medios productivos en manos del personal. Llegaría así un momento en que este adquiriera una mayoría que le permitiera asumir la gestión de las empresas, transformadas en empresas de gestión autónoma, tanto con relación a quienes concentraban el capital como al Estado. 
Este es un punto de gran trascendencia. La gestión autónoma concierne a grandes empresas cuya complejidad técnica y económica exige un fuerte sentido de responsabilidad en la elección de quienes han de formar los cuerpos directivos, los cuales, a su vez, deberán designar las personas que ocuparán los cargos ejecutivos. Se conciben diferentes formas de hacerlo. Una de ellas, acaso la más aconsejable, sería formar tres estamentos de igual gravitación: el estamento del personal superior de directores y técnicos; el de empleados medios y obreros calificados, y el de empleados de inferior jerarquía y obreros no calificados. Los representantes de estos tres estamentos integrarían el consejo directivo de cada empresa autónoma, a los que se agregarían representantes del Estado cuando este hubiera aportado recursos para la ampliación o renovación de la empresa.

Estos representantes participarían, junto a los de los propietarios actuales, en proporción a su participación en el capital, cuya composición social irá cambiando en la forma que se ha explicado más arriba.

En cuanto a las empresas de propiedad del Estado son bien conocidos los motivos que las justifican. Se refieren, sobre todo, a aquellos casos de actividades que por su índole se sustraen a la concurrencia en el mercado, a casos donde por sus dimensiones y complejidad técnica es importante la promoción por parte del Estado, y al designio de contrarrestar la penetración de la empresa extranjera en campos privativos de decisión del propio país.

Pero también sabemos que los resultados de la empresa pública no siempre son positivos. De ahí la conveniencia de dar participación al personal en su gestión, combinándola con la gestión de representantes del Estado. Más aún, no habría razones para sustraer a la fuerza de trabajo de la participación en el capital de tales empresas.

La empresa extranjera plantea un problema especial en cuanto a la acumulación. Pues contrariamente a lo que acontece en el caso de las empresas del país, el uso de parte del excedente se realiza fuera de la jurisdicción nacional. Este hecho y otras consideraciones aconsejan establecer un régimen especial. Entre estas consideraciones debe tenerse en cuenta que los cambios que el uso social del excedente provocarán en la demanda obligarán a ciertos reajustes en el funcionamiento de tales empresas que favorezcan su transferencia a manos nacionales.

En todo esto el Estado tendrá que proceder con criterio estrictamente selectivo, tanto en lo que concierne al establecimiento de nuevas empresas como al desplazamiento de la propiedad a manos nacionales del país, cuando se hubiera formado la capacidad técnica y económica para manejarlas en un régimen de gestión autónoma.

\section{Las desviaciones en el uso social del excedente}

Por más que el nuevo sistema se base en un cambio muy importante en la estructura del poder político, no por ello se habrán dominado las consecuencias de la heterogeneidad estructural de la fuerza de trabajo. Transcurrirá un tiempo más bien prolongado hasta llegar a una relativa homogeneidad social.

Mientras tanto, el nuevo sistema no podrá escapar a peligrosas tensiones que pudieran menoscabar el régimen de disciplina social de acumulación y distribución, con muy serias consecuencias políticas.

De acuerdo con el nuevo régimen institucional, ningún grupo social podría mejorar su compartimiento del excedente por su sola determinación. No me refiero por supuesto a las diferencias correspondientes a la contribución individual al proceso productivo, o sea las diferencias de índole funcional, sino a las de origen estructural. Solo podrá modificarse ese compartimiento según el procedimiento orgánico que se hubiera establecido, sujeto desde luego a las modificaciones que fuere necesario introducir. Pues bien, al mejorar un grupo social su participación relativa en el excedente empeoraría la de otros grupos, salvo que se hiciera en detrimento de la acumulación; otro tanto cabría decir de la parte que el Estado tome directa o indirectamente del excedente.

Adviértase la diferencia de fondo con el sistema vigente, donde esas distintas presiones se ejercen sin tener en cuenta su incidencia ulterior y sus efectos inflacionarios más allá de cierto punto.

Tal sería la racionalidad del nuevo sistema y su exigencia elemental de planificación. Pero la planificación, a pesar de su racionalidad, no bastará por sí sola para contener presiones dislocadoras. ¿Cómo conciliar los diferentes intereses inmediatos entre sí y lograr asimismo su compatibilidad con las exigencias de acumulación?

Muy lejos me encuentro de abrigar una ilusión mecanicista. Las más sabias y previsoras disposiciones constitucionales están siempre expuestas al riesgo de extravíos y violaciones. Pero se sabría cómo restablecer su regularidad, tal vez con algunas reformas aconsejadas por la experiencia; y lo mismo podría decirse del régimen institucional del excedente. El poder de ciertos 
grupos sociales podría salirse de su cauce y conseguir decisiones políticas que trastornen el nuevo sistema; o este podría sufrir las consecuencias de la irresponsabilidad populista. Pero de acuerdo con nuevas reglas del juego se conocería con precisión cuál es la incidencia social de esas desviaciones, y se sabría también cómo volver al funcionamiento correcto del régimen institucional del excedente: otra gran diferencia con el sistema presente, donde no hay reglas del juego que contengan la espiral inflacionaria.

Sin embargo, no se necesita gran imaginación para entrever las consecuencias de extravíos persistentes en cuyo curso los grupos de más poder político terminarían por minar las bases mismas del nuevo sistema. Los acontecimientos podrían así provocar el empleo de la fuerza, sea para imponer aquellas reglas del juego o para retornar autoritariamente al capitalismo periférico, o para imponer el autoritarismo estructural estableciendo el Estado omnipotente mediante la transferencia y gestión de los medios productivos.

Digo esto con gran franqueza, porque no creo haber encontrado una solución inexpugnable. Estoy muy consciente de los grandes obstáculos que habrá que vencer. No se trata en verdad de fórmulas que, una vez adoptadas, surtirán por sí solas sus efectos benéficos. Se necesitará una gran convicción, tanto para llegar a un nuevo sistema como para sobreponerse a los grandes obstáculos que surgirán en su funcionamiento.

¿Pero existe otro camino? ¿Un camino que permita combinar el vigor del desarrollo y la equidad distributiva con la libertad individual? Si lo hubiere, si esta discusión enderezara hacia ese otro camino, no vacilaría en seguirlo, desandando todo lo que laboriosamente he andado hasta ahora.

\section{El uso social del excedente y el grado de desarrollo}

De todo cuanto he dicho hasta ahora podría pensarse que mis razonamientos atañen solamente a los países de un grado avanzado de desarrollo y en los cuales el proceso de democratización se vuelve incompatible con el régimen de acumulación y distribución.

Sin embargo, no es así. En verdad, he puesto el acento en esos casos, tanto por la importancia que revisten, como para despejar la perspectiva que tienen por delante aquellos otros países de menor grado de desarrollo, si no aprovechan a tiempo la experiencia de los que están más avanzados.

Es cierto que hay diferencias muy pronunciadas.
En países de incipiente industrialización es elevada la proporción de la fuerza de trabajo que se encuentra en la agricultura y en otras actividades de escasa productividad. Y también suele ser muy alta la tasa de crecimiento demográfico. En consecuencia, el problema de absorción se presenta con muy grandes dimensiones relativas. ¿Cómo afrontarlo si el excedente es exiguo en la incipiente industria?

Es pues forzoso acudir al excedente real o potencial de la agricultura y otras fuentes de producción primaria. Es cierto que ello se impone asimismo en países de mayor grado de desarrollo; pero allí existen también excedentes en la industria y en otras actividades técnicamente avanzadas.

Ahora bien, en tales países de menor grado de desarrollo se presentan las dos situaciones que mencionamos en el capítulo IV, en materia de tenencia de la tierra. Propiedades técnicamente bien explotadas y propiedades que no lo son. En las primeras hay que captar el excedente para usarlo socialmente. En tanto que en estas otras debe crearse primero el excedente, forzando en una u otra forma su mejor explotación. Parte del excedente que se capte en uno y en otro caso tiene que emplearse tanto en la agricultura como en dar impulso a una industrialización ineludible.

Lo mismo podría decirse con referencia a los recursos naturales no renovables, donde una magnitud desproporcionada del excedente suele desplazarse a los centros.

Trátase de problemas de solución nada fácil, pero habrá que llegar a ella si un país ha de desarrollarse con vigor y equidad distributiva.

De cualquier manera, la experiencia de los países de mayor desarrollo demuestra que si en tales circunstancias no se obra deliberadamente sobre la acumulación y la distribución, se habrá seguido un cauce que desemboca necesariamente en los fenómenos excluyentes y conflictivos que tanto nos preocupan.

En efecto, tarde o temprano comenzará a tomar impulso el proceso de democratización, o a recuperarse si hubiera ocurrido un eclipse. Y como quiera que se trate de un movimiento espontáneo o violento, se impone precaverse a tiempo del riesgo que se corre si este proceso se orienta primordialmente hacia formas inmediatas de distribución olvidando exigencias dinámicas de decisiva importancia.

Por donde llegamos al mismo problema fundamental que es común a todos, cualquiera que fuere su grado de desarrollo: el de la acumulación, principalmente de capital reproductivo, a fin de asentar sobre bases firmes la distribución dinámica del ingreso. 
Si los movimientos inspirados por la equidad social no encaran este problema, la democratización se expone a devorarse a sí misma.

Las diferencias en cuanto al grado de desarrollo atañen más bien a quienes realizarán la acumulación y a los propósitos que han de perseguir. Desde luego, siendo incipiente la industrialización, la acumulación tendrá que efectuarse en las empresas pequeñas y medianas en manos de sus propietarios. Son las que con el tiempo evolucionarán hacia formas técnicas más avanzadas y mayores dimensiones productivas. Mediante el uso social del excedente podría apoyarse técnica y financieramente la iniciativa de los empresarios; papel muy importante, por cierto, para el Estado promotor. ${ }^{5}$

\section{III}

\section{El arte político de la transformación}

\section{Cambios en la estructura del poder político}

Es obvio que la transformación del sistema -ya se trate de la socialización del excedente o de los medios productivos- no podría acontecer sin cambios fundamentales en la composición del poder político.

Es cierto que estos cambios ocurren conforme se desenvuelven las mutaciones de la estructura social. Los movimientos políticos impulsados por el poder creciente de los estratos intermedios, al que se agrega eventualmente el de los estratos inferiores, van fortaleciendo su aptitud para compartir el excedente. Son, sin embargo, movimientos esencialmente distributivos, que no han ido al fondo del problema, si acaso pudieron haberlo hecho. En verdad, ha prevalecido la creencia de que en esta forma llegaría a corregirse gradualmente la inequidad del sistema y a alejarse así el riesgo de soluciones radicales.

Ahora es posible ver más claro que la democracia distributiva tiende a devorarse a sí misma al provocar el empleo de la fuerza.

Para decirlo sin ambages, frente a la opción de socializar los medios productivos, no se ha ofrecido otra opción que pudiera lograr un consenso mayoritario y evitar de esta manera el recurso a la fuerza. No me refiero, por supuesto, a la opción neoclásica que se sustenta en una flagrante supresión del proceso democrático.

El empleo de la fuerza no puede mantenerse indefinidamente. Como lo demuestra la experiencia, la fuerza se desgasta con el andar del tiempo, nuevos hombres toman la responsabilidad de ejercerla y crecen las aspiraciones populares de libertad política y equidad distributiva. Y si no se abren cauces al reestablecimiento institucional, el sistema se expone de más en más a violentas confrontaciones.
De todos modos, yo no podría discurrir acerca de estrategia política sin desbordar el propósito que estos escritos persiguen y, acaso, por mi falta de competencia. Por lo demás una estrategia tiene que tomar en cuenta las condiciones de la realidad, así en lo que atañe al desarrollo interno, como las relaciones con los centros. La difícil tarea que me he impuesto es otra: ¿Qué hacer cuando, cualquiera que fuere la estrategia, se hubiera logrado una composición del poder político favorable a la transformación del sistema?

El cambio en la estructura política es condición necesaria, pero no suficiente. $Y$ he procurado dar respuesta a esta pregunta explorando una nueva opción donde se combinen, como expresé en otro lugar, el vigor del desarrollo, la equidad social y la democracia participativa con la vigencia de los derechos esenciales que le son inherentes.

En esta exploración me he propuesto examinar especialmente los fenómenos que acontecen en el curso avanzado del desarrollo periférico. Considero que, tarde o temprano, han de presentarse en otros países, habida cuenta de sus particulares condiciones. Pero, mientras tanto, las crisis políticas de estos últimos son de otra índole.

Trátase de países donde no se ha abierto paso al proceso de democratización, sea porque a ello se

\footnotetext{
${ }^{5}$ No es el caso de entrar aquí a discurrir sobre las posibles aplicaciones del capital que se acumula, pero sí conviene subrayar la significación que podría tener la intervención del Estado en materia de comercio exterior. Aquí también es aleccionadora la experiencia pasada. No solo se impone la sustitución de importaciones, sino el estímulo de las exportaciones. Habrá que evitar la asimetría de la industrialización. Es cierto que ello depende en buena parte de la actitud de los centros que, como bien sabemos, no se han caracterizado por su aperturismo, si se me permite emplear a la inversa este vocablo. Frente a este hecho, es tanto más necesario retomar con vigor el camino tan prometedor del comercio recíproco.
} 
opone el poder dominante de los estratos superiores que concentran una gran proporción de la tierra y el capital, o porque este proceso está frenado o contenido por las distintas formas de cooptación o manipulación que caracterizan a una democracia aparente, donde las formas exteriores prevalecen sobre su sustancia genuina.

¿Podrá mantenerse indefinidamente la inhibición del proceso o su falseamiento? ¿Podrá el sistema resistir crecientes aspiraciones de democracia y equidad social? Si no fuera así y si sobreviniera un cambio importante en la estructura del poder de esos países: ¿Qué hacer? ¿Cómo escapar a las ilusiones de una democracia meramente redistributiva a fin de no repetir el proceso de aquellos países más evolucionados? La respuesta no podría ser la misma que en estos, aunque tampoco fundamentalmente distinta, como se verá a su tiempo.

Volvamos ahora a los países en donde ha avanzado el proceso de democratización. No obstante las diferencias ideológicas que caracterizan el pluralismo político de un régimen democrático, suelen haber coincidencias en formas de redistribución directa e inmediata y en la expansión de los servicios del Estado, prescindiendo de la necesidad primordial de acumulación. Sin embargo, este último, como lo hemos dicho con insistencia, es el único medio de conseguir una redistribución dinámica del ingreso y, por tanto, el mejoramiento persistente de los estratos desfavorecidos.

\section{La solución política de la crisis}

Sin embargo, cuando se agudiza la crisis del sistema, aparece una división irreconciliable entre quienes siguen firmemente adheridos a una ideología genuinamente democrática y aquellos que profesan otras ideologías de un sentido político sustancialmente diferente. Son demasiado conocidas esas discrepancias para que se justifique distraernos en una discusión bizantina acerca del empleo de palabras, aunque tales discrepancias terminan por convertirse en obstáculo infranqueable para una solución política de la crisis sustentada en un consenso mayoritario.

Con ser muy importante este obstáculo, no es el único. Los movimientos políticos que sostienen la necesidad ineludible de un Estado omnipotente, basado en un partido único y disciplinado, que permite disolver el poder de los propietarios privados de los medios productivos y tomar su gestión, cuentan con una doctrina articulada de la transformación que se proponen realizar; no sucede otro tanto con aquellos otros movimientos de signo democrático. Con frecuencia se discurre en estos últimos acerca de una sociedad que no sea ni capitalista ni socialista, y aunque tales movimientos se inspiran en la justicia distributiva, suelen abstenerse de atacar resueltamente el origen mismo de las grandes fallas del sistema, esto es, la apropiación privada del excedente.

Todo ello es muy serio y desconcertante. No es extraño que en estas circunstancias se pretenda cargar a los hombres políticos con la responsabilidad de no encontrar soluciones para resolver la crisis del sistema. Trátase, sin embargo, de una responsabilidad que quienes discurrimos sobre el desarrollo debemos compartir, y en grado sumo, pues no hemos sabido contribuir a la búsqueda de una nueva opción.

No hemos ofrecido esta nueva opción a los movimientos democráticos inspirados en la equidad social; ni tampoco a quienes emplean la fuerza en el empeño, no siempre logrado, de restablecer el funcionamiento regular del sistema. Mal podríamos sorprendernos cuando, arrastrados estos últimos por las circunstancias, y también por ciertas preferencias doctrinarias, se dejan atraer por la simplicidad de las fórmulas del liberalismo económico. ¡Y puesto que el poder sindical y político de la fuerza de trabajo ha violado las leyes del mercado, trayendo consigo el desquicio del sistema y su desintegración social, hay que suprimirlo para contener la inflación responsable de esos males!

He aquí nuestro problema fundamental. Es necesario ofrecer una nueva opción a los movimientos democráticos para prevenir a tiempo ese grave desenlace. Ya sea que la democratización se abra paso resueltamente donde no había podido desenvolverse, o que se restablezca donde se había suprimido.

Ya no se tendría en tales casos la opción de un liberalismo económico que solo puede mantenerse con el empleo de la fuerza. Y la falta de una nueva opción podría llevar a serías claudicaciones en quienes, inspirados en hondas aspiraciones de equidad social, pudieran dejarse atraer por la ilusión de que la transferencia de los medios productivos y de su gestión al Estado es el mejor camino para realizar esas aspiraciones sin sacrificar la pluralidad democrática.

Es notoria, por otro lado la gran efervescencia social de la Iglesia. Y compréndense las tribulaciones de teólogos y fieles que, heridos profundamente por el espectáculo de la gran desigualdad social, parecerían dispuestos a ciertos compromisos con ideologías de transformación cuya filosofía primigenia parecería irreconciliable con el poder espiritual de la Iglesia. No 
necesitan hacerlo. Espero que ellos quieran examinar las ideas que se exponen en este trabajo. Al escribirlas me ha impresionado fuertemente esta reciente declaración de Juan Pablo II: "sobre toda propiedad privada grava una hipoteca social". 6 ¿Se trata, acaso, de la hipoteca del uso social del excedente?

Además, ¿por qué no habría de presentarse también esta nueva perspectiva al poder militar? Nos hemos referido una y otra vez al empleo de la fuerza para implantar el liberalismo económico sin cambiar los fundamentos del sistema. Por mucho que no les preocupe necesariamente el costo político, que algunos consideran transitorio e inevitable, cuando no aceptable, es notorio que las consecuencias sociales de un falseado liberalismo económico terminan por desconcertar a muchos de ellos, consecuencias que se prolongan, cuando no se agravan, con el transcurso del tiempo.

No es extraño entonces que después de una fase de euforia -confortada con ciertas pruebas externas de admiración- vaya cundiendo el desconcierto acerca de esas graves consecuencias sociales de este tipo de desarrollo, además de su ingente costo político.

Los acontecimientos impulsan así aspiraciones crecientes de retorno a la normalidad, con algunos reajustes institucionales. Pero hay que llegar al fondo del problema. La normalidad exige, desde luego, restablecer el poder redistributivo de la fuerza de trabajo. ¿Cómo evitar entonces el desenvolvimiento de un nuevo ciclo político? ¿Cómo contener las tendencias conflictivas de una nueva espiral inflacionaria o de la acentuación de una espiral que no se hubiera conseguido extirpar? ¿Cómo contrarrestar las tendencias excluyentes del sistema que, lejos de atenuarse, suelen más bien agravarse en un régimen de fuerza?

Aleccionadas por aquella frustración de su experiencia, las fuerzas armadas podrían tal vez interesarse en examinar otras opciones, como las que aquí se exponen; pero no para imponerlas, sino para comprender

\footnotetext{
${ }^{6}$ En su discurso inaugural en la reunión del CELAM, el 28 de enero de 1979, hace explícita, además, el Sumo Pontífice, la misión evangélica de la Iglesia frente a la inequidad social en los siguientes términos: “...debe predicar, educar a las personas y a las colectividades, formar la opinión pública, orientar a los responsables de los pueblos. De este modo estará trabajando en favor de la sociedad, dentro de la cual este principio cristiano y evangélico terminará dando frutos de una distribución más justa y equitativa de los bienes, no solo al interior de cada nación, sino también en el mundo internacional en general, evitando que los países más fuertes usen su poder en detrimento de los más débiles".

"Aquellos sobre los cuales recae la responsabilidad de la vida pública de los Estados y naciones deberán comprender que la paz interna y la paz internacional solo estarán aseguradas si tiene vigencia un sistema social y económico basado sobre la justicia”.
}

el sentido de los movimientos democráticos que se propongan realizarlas.

A falta de aquellas otras opciones, nadie podría asegurar que el curso de los acontecimientos no las incline, también a ellas, a vencer ciertas resistencias doctrinarias a la opción socializadora de los medios productivos, que hasta ahora parecían ser muy fuertes.

\section{Significación política de la socialización}

La nueva opción que presentamos en las páginas anteriores se basa en el uso social del excedente. La sola mención de esta idea vuelve el pensamiento hacia la socialización de los medios productivos, puesto que de ellos surge el excedente. Parecería tratarse de una imposición lógica de la transformación del sistema.

Mas no lo creo así; voy a expresar las razones que me asisten. La socialización de los medios productivos y su gestión por parte del Estado tienen muy serias consecuencias políticas, tanto o más importantes, a mi juicio, que las consecuencias económicas. La socialización va unida de un modo indisoluble a un régimen político que difiere sustancialmente de los valores que han guiado y siguen orientando las grandes luchas de América Latina en favor de una democracia representativa y participativa, con plena vigencia de los derechos humanos fundamentales.

Me encuentro en una posición cómoda para expresarme sin ambages acerca de tales consecuencias, por la circunstancia de que estoy muy lejos de haber presentado en mi trabajo anterior la apología del capitalismo periférico. Lo he criticado tanto desde el punto de vista económico como del social y político. En consecuencia, cuando me opongo a la socialización de los medios productivos, no se interprete que lo hago para exaltar las virtudes de aquel capitalismo, ni mucho menos para defender su inequidad social.

Como quiera que fuere, tanto la socialización de los medios productivos como la transformación que estoy preconizando impugnan la apropiación privada del excedente. Una y otra tienen como punto común de partida el uso social de este último, pero es muy diferente el camino que ha de seguirse después.

La gestión de todos los medios productivos en manos del Estado otorga un poder incontrastable a quienes se encuentran en la cúspide de aquél, cualquiera haya sido la manera de llegar a ella. Las líneas de comando parten de allí. Y el curso vital de la fuerza de trabajo, o para decirlo mejor, de toda la población, su ingreso, su promoción, el discernimiento de méritos, dependen en última instancia de decisiones superiores. Y en ello 
se combinan no solamente la capacidad personal, sino la lealtad militante al sistema.

La unidad ideológica es elemento esencial de esta lealtad y de la estabilidad de este último. No se trata de una ideología que se nutre de la libre y espontánea expresión del pensamiento, sino que surge de quienes tienen la responsabilidad del poder y la necesidad de afianzarlo por distintos medios. No caben pues disidencias fundamentales que comprometan la unidad ideológica, la disciplina partidaria y la cohesión del sistema. Cohesión que podría verse comprometida si el ejercicio de la libertad de expresión traspusiera ciertos límites, o si la creación artística y literaria y la actividad intelectual salieran de los cauces trazados desde arriba. Tal es la cohesión inherente al sistema, e impuesta por el mismo, que no admite otra manifestación de autoridad.

Compréndese, por tanto, que la autoridad espiritual de la Iglesia se juzgue incompatible con la omnipotencia y omnisciencia del Estado.

A esa exigencia de cohesión en la doctrina y en la praxis no podrían escapar ni aun los hombres de la cúspide. Pues si unos disienten en cuestiones de peso, se incurre en el disfavor de los otros, lo cual es muy serio, pues quienes pierden su posición jerárquica en esas disputas internas no tienen la alternativa de emplear sus esfuerzos en la órbita de la actividad privada, que sencillamente no existe. La prolongación indefinida de los dirigentes en sus funciones, por dilatada que fuere, se vuelve pues factor importante de unidad forzada. ¡Estabilidad del sistema y gerontocracia!

Por lo demás, la serie de eslabones jerárquicos de decisión y vigilancia hacen posible sofocar en su propio germen cualquier atisbo de disconformismo sustancial. El sistema tiene su propia lógica interna y se necesita un temple excepcional para salirse de sus férreas exigencias.

\section{La desvirtuación del mercado}

Por lo demás, la propiedad y gestión de los medios productivos en manos del Estado va unida a un cambio fundamental en la índole del mercado, pues lo que se ha de producir y consumir depende, en última instancia, de una autoridad central. El mercado pierde así su significación política, que trasciende a la económica. Tampoco voy a idealizar en esto al capitalismo periférico; sin embargo, por más que el curso del desarrollo traiga consigo una creciente concentración del poder económico, el margen de libertad individual es considerable. Sin ella no se hubiera podido desenvolver el poder sindical y político de la fuerza de trabajo en el avance de la democratización. Solo que cuando ese poder trastorna la dinámica del excedente, el empleo de la fuerza permite suprimirlo.

Como he sostenido en mis trabajos precedentes, las grandes fallas del sistema no radican ni en el mercado en sí mismo, ni en la libertad económica sobre la que se asienta. Esas fallas surgen de la estructura social y de las relaciones de poder que pervierten la eficiencia social del sistema por la arbitrariedad de la distribución y la insuficiente acumulación de capital.

Es cierto que en un régimen fuertemente autoritario se concibe la libertad económica de las empresas y los individuos, factor esencial de eficiencia económica. Pero si esta libertad llegara a ser genuina, el núcleo dominante perdería un elemento de cohesión indispensable a la estabilidad del sistema y a su continuidad en el poder.

Más aún, si hay libertad económica y libertad de iniciativa en los dirigentes empresariales, y si estos surgen del seno mismo de las empresas y no de quienes concentran el poder político: ¿Cómo sería posible evitar que aspiren a la libertad de expresión y a la participación en las decisiones políticas? ¿Hasta qué punto cabría entonces separar la libertad política de la libertad económica? ¿No exigiría la lógica del sistema reprimir la libertad política de quienes, habiendo adquirido libertad económica, manifiestan discrepancias con tal sistema o la forma en que funciona? ¿Podría aislarse de estas consecuencias la libertad económica?

\section{Pluralismo político y socialización}

Detengámonos ahora un breve instante en una interpolación doctrinaria. En la teoría científica de Marx -que hay que distinguir del marxismo militante- las doctrinas son parte integrante de la superestructura, que está condicionada decisivamente por la estructura básica del sistema. Los cambios en la estructura, conforme se desenvuelven las fuerzas productivas, impulsan la modificación de la superestructura. No hay ideologías de valor permanente.

Me pregunto, entonces, si los cambios que han venido ocurriendo en la estructura son ajenos a las nuevas corrientes ideológicas que están surgiendo en otras latitudes, y a las cuales se les atribuye a veces un valor circunstancial y transitorio, más que una significación perdurable. De todos modos, habría que considerarlas dentro de un más amplio contexto doctrinario.

En estas nuevas corrientes se acepta de un modo explícito el pluralismo político, en contraposición al 
concepto, hasta entonces dominante, de dictadura del proletariado, como quiera que se le defina. El pluralismo es condición esencial del liberalismo democrático. Y no comprendo cómo podría conciliarse este último con un Estado omnipotente que concentra todos los medios de producción y desempeña la gestión de estos medios. Si realmente se persigue una transformación democrática, esas nuevas corrientes no podrían eludir la franca discusión de este problema.

\section{Algunos riesgos políticos iniciales de la transformación}

En estas páginas estoy desplegando una acción persuasiva. Quiero llevar al ánimo de mis lectores que hay una opción transformadora compatible con la democracia y que es necesario explorarla a fondo. De llegarse a resultados positivos, ello sería apenas el primer paso para inspirar e impulsar amplios movimientos políticos que puedan traducirse en consenso mayoritario.

Sin embargo, hechos ulteriores podrían desvirtuar ciertos elementos básicos de la transformación hasta comprometer la existencia del nuevo sistema.

Entre esos elementos quisiera mencionar la colaboración de los actuales propietarios de grandes empresas que desempeñan efectivamente tareas directivas. En nuestros países todavía son importantes esas tareas empresariales de los propietarios. Hay que darles la oportunidad de continuar ofreciéndoles suficientes incentivos, aunque, es cierto, ya no podrán disponer del excedente, pues la clave dinámica de la acumulación pasará al Estado. Pero los propietarios seguirían percibiendo el interés correspondiente al capital acumulado en la misma forma que la fuerza de trabajo que acumulara nuevo capital. Los propietarios recibirían además la remuneración que les correspondiera por sus tareas empresariales y otros incentivos vinculados a la productividad global de las empresas.

$\mathrm{Si}$ a pesar de ello hubiera resistencias obstinadas a aceptar el nuevo orden de cosas, quienes tengan la responsabilidad política del nuevo sistema podrían verse llevados a transferir todos los medios productivos al Estado. Así pues, en vez de un cambio gradual en la composición del capital de las grandes empresas hasta llevar a su gestión a la fuerza de trabajo, se habría pasado súbitamente a la propiedad y gestión del Estado.

Es fácil comprender las serias perturbaciones que traería consigo esta alteración de algunos de los elementos básicos del nuevo sistema. No se trataría solamente de las grandes empresas. Explicamos ya que las empresas medianas acrecentarían su acumulación en manos de sus actuales propietarios. Pero al aproximarse en dimensiones a las grandes empresas, aquellos correrían el riesgo de que, precisamente por haber acumulado más, quedarían expuestos a que el capital y la gestión se transfirieran al Estado. Se debilitaría pues el impulso de crecimiento, de tanta significación en el nuevo sistema.

Tanto o más serios serían estos efectos si se desconociera la necesidad de brindar incentivos especiales a los ejecutivos, técnicos y demás miembros del personal de las grandes empresas. La colaboración de este personal es de la mayor importancia en sí misma; y mucho más cuando no se pudiera contar con la de los propietarios. Si se llegara a prescindir de este personal por exceso de celo político, solo con el andar del tiempo se podría llenar este vacío. Y, entonces, habría que ofrecer incentivos similares a los que habrían dejado de darse anteriormente.

Con sentido fuertemente realista debo reconocer que las grandes dificultades iniciales de la transformación -no solo interna, sino también internacional-, pudieran llevar a los hombres responsables a cierto autoritarismo, un autoritarismo coyuntural si se quiere, pero de todos modos sumamente lamentable. Se necesitaría una gran convicción para evitar que ello se transformara en autoritarismo estructural. No cabe duda que ante resistencias enconadas, la transferencia al Estado de la propiedad y gestión de los medios productivos sería un instrumento formidable de autoridad suprema de carácter estructural. Y se habría cerrado, acaso por un tiempo dilatadísimo, el cauce del avance democrático. 


\section{IV}

\section{Técnica, demanda y estructura productiva}

\section{Consecuencias de la desigual distribución}

En mi análisis crítico del capitalismo periférico he atribuido, en gran parte, a la desigual distribución del fruto del progreso técnico, la explicación de las grandes fallas del capitalismo periférico. El uso social del excedente se propone corregirlas, según se ha visto en páginas precedentes.

La desigual distribución influye de dos maneras principales sobre la estructura productiva. Por un lado, imprime a la demanda una conformación que hace desperdiciar capital físico y fuerza de trabajo; $y$, por otro, promueve cierta elección de técnicas, y por tanto formas de acumulación, que también representan un desperdicio de recursos productivos. Creo que el régimen de acumulación y distribución que preconizo permitirá corregir en gran parte esas deficiencias de la estructura productiva.

Pero ello no sería suficiente, pues la penetración de la técnica de los centros en una estructura social periférica muy diferente de la de aquellos, trae consigo ciertas consecuencias adversas al eficaz empleo del capital, que no podrían corregirse bajo el signo de ese nuevo régimen, sino que requieren una intervención deliberada del Estado en la estructura productiva.

Se me ha criticado y, con razón, por haber puesto de lado esas consecuencias adversas, así como otras provenientes de la incorrecta elección de técnicas, en mi afán por subrayar la influencia prevaleciente del régimen de acumulación y distribución que caracteriza el capitalismo periférico.

En verdad, nada me ha costado tener en cuenta los fenómenos a los que la crítica se refiere, pues los he examinado en trabajos precedentes de esta Revista y en otras publicaciones anteriores. Así pues, en este capítulo quisiera presentar sucinta y coherentemente esas explicaciones y subrayar su significación.

Advierto que en esto podría haber algo más que una simple cuestión de acento teórico, pues no me sorprendería que la influencia de tales fenómenos, que afectan a la estructura productiva, aliente cierta tendencia favorable a que el Estado tome a esta en sus manos valiéndose de la socialización de los medios productivos. Considero que desde el punto de vista del uso social del excedente, la socialización y la gestión de tales medios por el Estado no es admisible, por razones fundamentalmente políticas que expuse en su momento, además de sus consecuencias económicas. Pues no cabe duda que ello significaría otorgar al Estado un poder considerable e incompatible con la vigencia de libertades esenciales.

Si ello es así, mal podría recurrirse a la socialización, no ya para resolver el problema de acumulación y distribución, sino para corregir deficiencias que podrían persistir en un nuevo sistema, a pesar del uso social del excedente. Sostengo que el Estado puede disponer de otros medios para hacerlo.

\section{Técnicas reproductivas y consuntivas}

Para comprender los cambios que ocurren en la estructura productiva en el curso del desarrollo hay que recordar el significado de la dualidad de la técnica; por un lado, las técnicas que persiguen el aumento de la productividad; $\mathrm{y}$, por otro, las orientadas principalmente a conseguir la diversificación de bienes y servicios.

Hemos llamado reproductivo al capital que requieren las primeras técnicas, por cuanto el aumento de productividad que con estas se consigue permite acrecentar la acumulación con nuevos incrementos de productividad, y así sucesivamente, en un proceso multiplicador del empleo.

Las técnicas de diversificación también requieren capital, pero no para lograr una mayor productividad, sino para conseguir bienes y servicios más eficientes, de mejor calidad o que satisfagan aspiraciones de variedad de vida y consumo conspicuo, así como de prestigio social y ostentación de riqueza.

Estas técnicas de diversificación no podrían desenvolverse sin las técnicas reproductivas. Es el aumento de productividad y de los correspondientes ingresos que aportan estas técnicas lo que aguija el progreso de las técnicas de diversificación, a fin de estimular y captar la demanda creciente generada por tales ingresos.

No tendría sentido, en verdad, producir abundantemente los mismos bienes y servicios más allá de ciertos límites, gracias a la mayor productividad. Por el contrario, la diversificación permite emplear el crecimiento del ingreso en un despliegue incesante de nuevos y mejores bienes cada vez más cuantiosos. 
El progreso de las técnicas de diversificación es pues una consecuencia lógica de las técnicas reproductivas que se combinan estrechamente con las otras de un mismo proceso productivo. Tiende así a subir la proporción de las primeras en la composición del capital.

Ahora bien, al distribuirse tan desigualmente el fruto de la productividad, el empleo de las técnicas de diversificación se desenvuelve más intensamente de lo que ocurriría de otro modo. Aumenta así en forma exagerada la proporción de capital consuntivo, a expensas del capital reproductivo. Y esto reviste considerable importancia en el capitalismo periférico.

Este desperdicio social del capital es uno de los factores más importantes del sentido excluyente del capitalismo periférico. Hay casos en que ha aumentado extraordinariamente la productividad debido a la introducción de nuevas capas técnicas, pero debido a su desigual distribución, el fruto de este aumento de productividad se dedica en gran parte a satisfacer el consumo diversificado de los estratos favorecidos, en desmedro de la integración social de los estratos inferiores.

\section{Sociedad de consumo y acumulación}

Una de las críticas que se me han dirigido señala precisamente casos en que se ha desenvuelto de manera notable la sociedad privilegiada de consumo y, a pesar de ello, se ha logrado un alto coeficiente de acumulación. No hay pues insuficiencia de capital, se nos dice.

Sin embargo, la insuficiencia se manifiesta en el capital reproductivo. Este fenómeno se agrava cuando la supresión del poder sindical y político de la fuerza de trabajo consigue comprimir las remuneraciones reales en favor de estratos sociales más elevados. Estos estratos pueden entonces acrecentar más aún su consumo diversificado y su acumulación consuntiva.

Recuérdese de paso lo que dijimos en trabajos anteriores. Una parte apreciable de esta última acumulación corresponde a la inversión conspicua en viviendas costosas por parte de aquellos estratos, así como ciertas inversiones del Estado que escapan a consideraciones de economicidad. No basta, pues, comprobar que ha subido el ritmo de acumulación; es preciso saber también qué es lo que se acumula.

Conviene hacer aquí una observación adicional antes de dejar este aspecto. Si con el desarrollo no solo se busca la eficiencia económica sino también la eficiencia social, la acumulación consuntiva debe tener una adecuada relación con la acumulación reproductiva. Sin embargo, la desigual distribución del ingreso impulsa la demanda hacia bienes y servicios diversificados que exigen aumentar la acumulación consuntiva. Se emplea de esta manera capital escaso, no obstante haber capital acumulado y, por tanto, capacidad disponible para producir bienes similares, aunque con técnicas menos avanzadas y menor grado de diversificación. Esta desviación de la demanda lleva a desperdiciar el capital invertido en estos bienes inferiores, y aumentar la inversión de capital consuntivo, mientras es socialmente insuficiente el capital reproductivo.

Es claro, sin embargo, que en el curso del proceso de desarrollo esas técnicas inferiores terminan por abrir paso a técnicas más avanzadas de diversificación, como ha ocurrido generalmente con el desarrollo capitalista de los centros. Pero este proceso se anticipa prematuramente en el capitalismo periférico.

Todavía cabe agregar algunas consideraciones pertinentes acerca de la demanda y la estructura productiva.

Es notorio que los medios masivos de difusión social, tan estrechamente vinculados a la sociedad privilegiada de consumo, emplean todas las formas de sugestión colectiva disponibles para extender el consumo de bienes diversificados. Y de esta manera tratan insistentemente de penetrar hacia abajo en la estructura social, propagando allí la imagen atrayente de ciertos bienes que los estratos superiores van dejando atrás al adoptar las nuevas formas con que se manifiesta continuamente el proceso de imitación a los centros. Está de más mencionar que el abuso crediticio en que se incurre en estas campañas de sugestión colectiva suele desempeñar un papel muy activo.

Por supuesto que las empresas transnacionales tienen una gran responsabilidad en la promoción del consumo imitativo. Pero me inclino a pensar que, aun sin ellas, se habría desenvuelto la sociedad privilegiada de consumo debido, sobre todo, a la desigualdad distributiva, como tantas veces lo hemos visto. ¡No se subestime el vigor de nuestro genio imitativo!

Por cierto que al perder importancia la sociedad privilegiada de consumo, los medios masivos de difusión social y las empresas transnacionales verían comprimirse notablemente su campo de acción. Pero es posible que sobrevivan ciertas formas exageradas de diversificación que afectan adversamente la acumulación reproductiva.

El Estado tendría, pues, que intervenir en forma deliberada valiéndose del impuesto, esto es, elevando los precios de los bienes donde se manifiesta principalmente esa tendencia a ciertas extralimitaciones del consumo.

Pero entiéndaseme bien. Aliento francamente la intervención del Estado por razones de acumulación 
o de carácter sanitario, y la necesaria en defensa de la biosfera. Tal como se justifican los impuestos y subsidios para influir sobre la estructura productiva en materia de comercio exterior, o sea donde el mercado no tiene eficacia.

Pero fuera de esto, considero esencial asegurar la libertad del individuo para seguir sus propias preferencias en materia de consumo, como en la vasta gama de actividades humanas, mientras no perjudique la libertad de los demás.

Pues, ¿cómo justificar que el Estado se sobreponga a esas preferencias y decida en lugar del individuo? ¿Qué razones habría para que tome en sus manos la estructura productiva a fin de conseguir este designio autoritario? $¿ \mathrm{O}$ para que use una extensa gama de impuestos para desvirtuar esas preferencias?

\section{Las alternativas de acumulación}

Veamos ahora otro aspecto de la penetración de la técnica en la estructura social. La distribución del ingreso, en efecto, influye también sobre la elección de alternativas técnicas y, a través de ese mecanismo, sobre la estructura productiva, favoreciendo combinaciones de capital y fuerza de trabajo contrarias a la absorción de esta última.

Es un hecho bien conocido que las técnicas originarias de los centros significan una gran contradicción: economizan mano de obra abundante y exigen intensificar el empleo del capital escaso. Creo que en la CEPAL hemos estado entre los primeros en examinar este fenómeno ya a comienzos de los años cincuenta. ${ }^{7}$

Esta incorrecta elección de técnicas, con el correspondiente desperdicio de capital, se explica sobre todo por un falseamiento de los precios relativos. He sostenido en otra oportunidad que el interés del capital y el nivel de salarios no responden a lo que suponen las teorías neoclásicas y su concepción de equilibrio. En el fondo, encontramos el fenómeno del excedente que aquellas teorías ignoran. Gracias al excedente, las empresas solo tienen que acudir al mercado para una parte de sus necesidades de acumulación, con lo cual la tasa de interés resulta inferior a lo que sería de otro modo. Además, el nivel de salarios no es el que determina de manera espontánea el mercado, sino que está considerablemente influido por la pugna de la fuerza de trabajo para compartir el excedente, tanto por su poder sindical como por su poder político.

\footnotetext{
${ }^{7}$ Problemas teóricos y prácticos del crecimiento económico, Naciones Unidas, serie conmemorativa del XXV Aniversario de la CEPAL, Santiago, 1973 (Primera versión, 1951).
}

En verdad, en los casi treinta años transcurridos desde que llamamos la atención sobre esos fenómenos, no parecerían haberse presentado esas alternativas tecnológicas, salvo de una manera muy parcial y limitada.

Mientras tanto, se ha discurrido mucho acerca de cómo aproximarse a precios que reflejen mejor la realidad. Se ha hablado de impuestos sobre los bienes de capital o subsidios al empleo de fuerza de trabajo para responder mejor a la disponibilidad de estos factores productivos. Estas y otras ideas no han prosperado, sospecho que por no haberse avanzado suficientemente en materia de alternativas tecnológicas que están fuera del interés inmediato de los centros.

Hay otra forma de desperdicio de capital estimulada por el falseamiento de los precios relativos. En países como los nuestros, con escasez de capital, llama la atención que las fábricas trabajen generalmente un solo turno, cuando podrían hacerlo durante dos o tres turnos. Pero no se trata solamente de ese falseamiento sino también de otros obstáculos que se oponen a este mejor aprovechamiento del capital. Como sería difícil, si no imposible, recurrir en estos casos a precios especiales, se ha discurrido acerca de diversas medidas que podrían promover el aprovechamiento del capital.

Finalmente, en otras críticas se hace hincapié en que a medida que se introducen nuevas capas técnicas de mayor productividad que las precedentes, el descenso de los precios lleva a la liquidación de las empresas afectadas, con la consiguiente pérdida de capital. Es un argumento que suele presentarse con cierta frecuencia. ¿Pero hasta qué punto es un fenómeno del capitalismo periférico?

Me inclino a creer que el fenómeno general es de otra naturaleza, pues, como ya lo hemos demostrado, los precios no tienden a bajar conforme aumenta la productividad. No creo que la competencia de precios, en casos semejantes, constituya un hecho frecuente. En la dinámica del desarrollo las nuevas inversiones se orientan más bien a aprovechar el crecimiento de la demanda que se diversifica, antes que a desalojar violentamente del mercado a empresas de costos más elevados. Ello permite cosechar las ganancias para sí en vez de esparcirlas por el descenso de los precios. El medio para captar el mercado no es este último, sino la oferta de nuevos y mejores bienes.

Dejo abierta, sin embargo, la posibilidad de que se presenten pruebas en contrario. De todos modos, me pregunto si en tal caso habría que acudir al sistema de precios u otras formas adecuadas de intervención, o caer en la gestión estatal de los medios productivos. 
Sin embargo, aún admitido este último supuesto, podría discutirse si aquella intervención tendría que efectuarse mediante instrucciones generadas desde el comando superior del sistema, o si se acudiría también al sistema de precios y al juego del mercado, a fin de morigerar la burocratización creciente del sistema, que tanto preocupa en todas partes, sin exceptuar a los países socialistas.

\section{El sistema de precios}

Permítaseme ahora una breve digresión. Tan pronto como se menciona la posibilidad de emplear el sistema de precios con fines como los mencionados, se corre el riesgo de que se descubra en ello algún resabio de neoclacisismo. No es así, terminantemente.

En verdad, las teorías neoclásicas se han apoderado por completo del sistema de precios como si fuera privativo de sus lucubraciones. En verdad es la quintaesencia de sus razonamientos acerca de la tendencia hacia el equilibrio del sistema, si no se lo perturba con intervenciones artificiosas. Pero el sistema de precios ha existido durante largos siglos de precapitalismo. No se explicarían en otra forma, ni el famoso edicto del Emperador Diocleciano, ni las admoniciones tomistas en el medioevo. Sucede, sin embargo, que los neoclásicos lo convirtieron, dogmáticamente, en supremo regulador de la economía.
Para que el sistema de precios cumpla este papel regulador los neoclásicos admiten desde luego ciertas intervenciones, a fin de corregir las así llamadas imperfecciones del mercado. Recurren para ello a impuestos que permiten corregir esas imperfecciones, como en el caso de aquellas desviaciones de la técnica a los que nos referimos oportunamente.

Por este camino, sin embargo, podría llegarse muy lejos, como cuando se preconiza el sistema de precios para proteger el medio ambiente. ¿Podría decirse que el serio deterioro que este ha venido sufriendo se debe a imperfecciones del mercado? ¿No sería más correcto hablar de las consecuencias nocivas del juego irrestricto de las leyes del mercado?

Hay también economistas neoclásicos que reconocen plenamente que las leyes del mercado no resuelven los graves problemas de la distribución del ingreso en los centros. Si se asomaran con más detenimiento a la periferia, comprobarían que aquí las leyes del mercado tampoco resuelven el importantísimo problema de acumulación de capital. Si ello es así, ¿qué queda del papel de supremo regulador de la economía atribuido a esas leyes?

Las teorías neoclásicas ignoran la estructura social y sus mutaciones, así como las relaciones de poder que las acompañan y su considerable significación en la distribución del ingreso. ¿Cómo podrían impugnar entonces la sociedad privilegiada de consumo?

\section{V}

\section{La especificidad del capitalismo periférico}

\section{El capitalismo imitativo}

Podría preguntárseme ahora, ¿por qué una teoría de la transformación? ¿No sería posible reproducir en la periferia el desarrollo capitalista de los centros?

Esta pertinaz ilusión podía justificarse hace algunos decenios, pero no ahora. Se está desvaneciendo, en verdad, la ilusión de desarrollarnos a imagen y semejanza de aquellos países donde el bienestar se ha difundido a las grandes masas de la población (aunque tampoco del todo) y se ha desenvuelto vigorosamente el proceso de democratización (aunque no exento de defectos).

¿Qué diferencia nuestro capitalismo imitativo del capitalismo desarrollado e innovador? Hemos tratado de explicarlo en nuestros trabajos. Y ahora, antes de ocuparnos de las relaciones con los centros, parece conveniente subrayar los rasgos específicos del capitalismo de nuestras tierras, que en verdad son muy importantes.

Recuérdese que hemos caracterizado el desarrollo periférico como un proceso de irradiación y propagación desde los centros de técnicas, modalidades de consumo y demás formas culturales, ideas, ideologías e instituciones. Todo ello en una estructura social fundamentalmente diferente. Allí se encuentran las contradicciones de donde surgen las grandes fallas internas del capitalismo periférico.

Este proceso imitativo se cumple bajo el signo histórico de la hegemonía de los grandes países desarrollados, principalmente de los Estados Unidos, bajo 
el impulso de un capitalismo cuyo carácter centrípeto ha tenido y sigue teniendo relevante significación, como que es el origen de las grandes contradicciones que también se presentan en las relaciones con aquellos países y que acentúan las grandes fallas del desarrollo periférico.

A esto último dedicaremos el capítulo siguiente; en tanto que aquí recordaremos sucintamente aquellos rasgos específicos evocando lo expuesto en otras oportunidades.

La especificidad que caracteriza la estructura social periférica concierne principalmente a la técnica y al consumo, al grado de desarrollo y la democratización, a la tenencia de la tierra, a la formación del excedente, y al crecimiento demográfico.

\section{Técnica y consumo}

Debido a la gran heterogeneidad de la estructura social, el fruto de la penetración de la técnica es apropiada, principalmente, por los estratos favorecidos. No niego, por supuesto, que haya pasado lo mismo durante la evolución histórica del capitalismo de los centros. La diferencia está en que, gracias a esa forma de distribución se adoptan, en la periferia, modalidades de consumo que se han desenvuelto gradualmente en los centros, conforme la acumulación de capital permitía a la técnica penetrar cada vez con mayor profundidad en la estructura social. En la periferia, por el contrario, imitamos esas formas de consumo cuando la acumulación no basta para cumplir la función absorbente de fuerza de trabajo. Y esto se agrava con la succión de ingresos que los centros realizan por su supremacía técnica y económica y por la gravitación de su hegemonía. Compréndasenos bien. La especificidad no está tanto en la imitación del consumo de los centros, que es en rigor un fenómeno planetario, sino en las dimensiones que este fenómeno adquiere en la periferia, gracias a la flagrante desigualdad distributiva. En otros términos, la especificidad atañe al carácter privilegiado de la imitación.

Ello se acentúa porque el progreso técnico de los centros no favorece alternativas técnicas que respondan mejor a las condiciones periféricas, de donde resulta una de las más graves contradicciones del desarrollo imitativo; lo que hace tanto más necesario, pues, aprovechar a fondo el potencial del excedente.

\section{Grado de desarrollo y democratización}

Por otro lado, el proceso de democratización se ha abierto paso y desenvuelto en los centros cuando se había conseguido una considerable acumulación de capital. En tanto que la democratización periférica se desenvuelve antes que la acumulación responda a las exigencias dinámicas del desarrollo; además la democratización toma un sesgo esencialmente distributivo, y también conflictivo.

Adviértase que no estoy deplorando una democratización prematura, sino subrayando las serias consecuencias de haberse empeñado en una distribución inmediata dejando de lado la ineludible exigencia de acumulación de capital.

A ello se agrega la tendencia a la desmesurada expansión de los servicios del Estado, que en gran parte también responde a las diferentes formas de presión distributiva y de absorción espuria de fuerza de trabajo. Pero no podría olvidarse que a ello suele añadirse la fuerte presión de los gastos militares; no ha de sorprender, en consecuencia, que los gastos del Estado representen una proporción del producto que los países desarrollados tardaron mucho tiempo en alcanzar.

\section{La tenencia del suelo}

Desde otro punto de vista, no cabe duda que el régimen prevaleciente de tenencia de la tierra ha sido y sigue siendo un obstinado obstáculo al desarrollo, como tantas veces lo ha expresado la CEPAL. En los centros industriales se había logrado eliminar tempranamente este obstáculo con favorables consecuencias sociales y técnicas. Pero no así en la periferia, donde la industrialización se superpone a un régimen de tenencia que suele frenar la penetración de la técnica y la productividad, en detrimento del desarrollo. He aquí otro rasgo de especificidad del desarrollo periférico que pasamos a examinar.

Al discurrir acerca de la estructura productiva, nos hemos referido a la diversificación de la demanda. Esto concierne sobre todo a los bienes industriales y los servicios calificados; pero no a la agricultura, donde la diversificación es muy limitada. La demanda tiende pues a orientarse de más en más hacia esos bienes y servicios en desmedro de aquella. Y la ocupación tiende a desplazarse a las actividades diversificadas. Desciende pues la proporción de la agricultura en la estructura productiva y la ocupación. Esa tendencia al desplazamiento de fuerza de trabajo se acentúa a medida que se eleva la productividad.

Pero no es solo esto. La distribución regresiva del ingreso y la insuficiente acumulación de capital, en perjuicio principalmente de los estratos inferiores, explican que la demanda de alimentos sea relativamente débil a pesar de la manifiesta deficiencia del consumo. 
Esto lleva con frecuencia a frustrar las consecuencias favorables que podría tener el aumento de productividad; no hay demanda para absorber la mayor cuantía de bienes. Y la tendencia al deterioro de la relación de precios que ello trae consigo desalienta el aumento de la producción.

Véase, pues, aquí una de las más flagrantes contradicciones del sistema. La desigual distribución desplaza el crecimiento de la demanda hacia bienes cada vez más diversificados, en detrimento de bienes menos diversificados o de escasa o ninguna diversificación, como son los bienes agrícolas.

Si se aprovechara a fondo el potencial de acumulación del excedente, la demanda y la estructura productiva adoptarían una conformación diferente en favor de los estratos sociales menos favorecidos.

Sin embargo, no todo es cuestión de demanda. El régimen de tenencia de la tierra que caracteriza la estructura productiva, parece innecesario decirlo, tiene primordial importancia cuando prevalece la concentración de la gran propiedad. Según sucede generalmente en América Latina, la cuantiosa renta que se deriva de la tierra, desmesurada por su misma extensión, vuelve indiferentes a muchos propietarios a las posibilidades que ofrece el progreso técnico, sobre todo en materia de rendimientos. Por eso les atrae más la mecanización, pues no necesitan dedicar a la tierra todo el tiempo que exige la aplicación de técnicas biológicas.

Es cierto que durante los decenios recientes estas técnicas se estuvieron extendiendo con ponderables efectos sobre la productividad. Pero el gran propietario, renuente a hacerlo, comprueba sin embargo, que aumenta el valor de su predio en virtud de su mayor capacidad potencial. He ahí un hecho muy importante que caracteriza también la tierra urbana: la valorización del suelo por el trabajo ajeno, además del crecimiento de la población.

Reflexiónese sobre el contraste que ello representa, con el capital físico, para comprender mejor el caso de la agricultura. El propietario de capital físico, que se abstiene de utilizar el progreso técnico, no ve aumentar el valor de lo que posee sino todo lo contrario, pues termina por ser desalojado por empresarios más alertas al progreso técnico.

Parecería, como acaba de expresarse, que en materia de productividad agraria hay un avance perceptible en América Latina. Pero conforme se va eliminando una de las grandes fallas va surgiendo otra. Es cierto que al difundirse el progreso técnico en la agricultura se acrecienta el excedente; en buena hora así sea. Pero desgraciadamente la cuantía exagerada que se dedica a la sociedad privilegiada de consumo y se gira al exterior tiene efectos negativos sobre la acumulación de capital.

El excedente agrícola, por lo demás, se cristaliza en el valor del suelo, si se me permite la expresión. Y con ello agrava el fenómeno de concentración de la riqueza.

La agricultura presenta pues características muy especiales. Si no se introduce el progreso técnico, el excedente resulta inferior al que podría lograrse. Y si se introduce y acrecienta el excedente, y este se dedica el consumo conspicuo, se malogra su potencial de acumulación. En uno y otro caso son francamente desfavorables las consecuencias sobre la absorción de fuerza de trabajo y la distribución del ingreso.

Más serias son aún esas consecuencias cuando se introduce la mecanización y se desperdician las posibilidades de acumulación por el mayor excedente que trae aparejado. Aun cuando la mecanización respondiera a estrictos criterios de economicidad, ese desperdicio impide emplear la fuerza de trabajo que se desocupa y contribuir a la absorción de la que tenía escasa productividad, en virtud del poder multiplicador del capital reproductivo. En consecuencia, al desperdicio del potencial de acumulación se añade el desperdicio de potencial humano, ya sea que permanezca redundante en el campo, o vaya a engrosar las filas de los pobres en las ciudades.

Esta observación concierne también a quienes, al aducir que la mecanización no se puede introducir en pequeños predios agrícolas, preconizan la gran propiedad. ¿Pero a dónde iría la gente desplazada? No se quiere ver la otra cara de la economicidad. Téngase en cuenta, por lo demás, que en la pequeña propiedad, así como en la mediana, los rendimientos por unidad de tierra suelen ser más elevados que en las grandes propiedades, sobre todo si es eficaz la acción técnica del Estado. Es una forma socialmente eficiente de retener fuerza de trabajo en el campo hasta que la aceleración del desarrollo -la transformación del sistema- haga posible la solución de fondo de este grave problema.

\section{La eutanasia del excedente}

Volvamos ahora a fijar nuestra atención en el excedente, en torno al cual han girado nuestras explicaciones teóricas. No es por cierto su apropiación un fenómeno periférico, sino universal del capitalismo; pero también aquí se manifiesta la especificidad periférica. Conviene detenerse aquí un instante, por ser esto de bastante significación. 
Hemos explicado fundamentalmente este fenómeno estructural por la competencia regresiva de la fuerza de trabajo que permanece en capas técnicas de menor productividad, cuando nuevas capas técnicas de mayor productividad se sobreponen a estas últimas.

Reflexiónese bien sobre las consecuencias de este fenómeno. Gracias a la acumulación de capital que el excedente posibilita, la técnica ha penetrado en profundidad en los centros $\mathrm{y}$, al absorber fuerza de trabajo de menor productividad de los estratos inferiores, ha ido atenuando espontáneamente en el sistema la competencia regresiva que impide a la fuerza de trabajo mejorar sus remuneraciones correlativamente a la creciente productividad.

Así, pues, el excedente tendería a disminuir y, finalmente, a desaparecer, conforme va atenuándose la heterogeneidad de la técnica. Se concibe así un grado de desarrollo en que toda la fuerza de trabajo esté empleada en capas superiores con las técnicas más avanzadas que se dan en un momento determinado. Se habría extinguido entonces el excedente por haberse eliminado en el sistema una fuente importante de aumento de productividad, además de la presión creciente que ejerce sobre el mismo el intenso acrecentamiento de los servicios del Estado.

Quedaría, sin embargo, otra fuente importante: el aumento de productividad proveniente de sucesivas innovaciones.

$\mathrm{Al}$ aproximarse el sistema a su homogeneidad sobrevendría la eutanasia del excedente, y los economistas neoclásicos podrían regocijarse con la ilusión de haber alcanzado esa fase ideal en que la competencia entre empresarios haría desaparecer rápidamente el fruto de aquellos sucesivos incrementos de productividad por el aumento de remuneraciones. Más aún, podrían señalar las consecuencias favorables del juego irrestricto del mercado, sin necesidad de poder sindical y político. Pero la ilusión podría ser muy fugaz, pues la eutanasia del excedente plantearía un serio problema de acumulación. En efecto, nada hay en el sistema que lleve espontáneamente a la fuerza de trabajo a compensar con su propia acumulación lo que ya no podrían seguir haciendo los estratos superiores.

Esta digresión nos permite comprender mejor la índole estructural y esencialmente dinámica del excedente. En resumidas cuentas, se trata de una categoría histórica en el desarrollo del capitalismo.

Por supuesto que la periferia dista mucho de esta situación debido tanto a su gran heterogeneidad estructural como al desperdicio del potencial de acumulación. Este desperdicio dificulta sobremanera la absorción de los estratos inferiores y de los estratos intermedios de la fuerza de trabajo que se insertan espuriamente en el sistema. He aquí este otro elemento de especificidad periférica.

Y como hemos explicado en otro lugar, la doble presión del Estado y de la fuerza de trabajo sobre el excedente en la periferia tiende a llevar al sistema, mucho antes de un lejano fenómeno de eutanasia, a una fase crítica, pues cuando esa doble presión llega a vulnerar la clave dinámica del sistema en desmedro de la acumulación y el consumo privilegiado de los estratos superiores, el sistema reacciona con el alza de precios, lo cual lleva fatalmente a la espiral inflacionaria. Y la espiral no trae consigo, por supuesto, un nuevo régimen de acumulación. No digo que los centros escapen a esta tendencia aunque allí suele darse en condiciones diferentes.

\section{Especificidad del crecimiento demográfico}

Cuando los adelantos técnicos que defienden y prolongan la vida humana hacen descender la tasa de mortalidad de los centros, las mutaciones de su estructura social, y las consecuencias psicosociales que traen aparejadas, favorecen también el descenso en las tasas de natalidad. En tanto que la rápida penetración de esas mismas técnicas en la periferia ocurre en una estructura social donde tienden a prevalecer elevadas tasas de natalidad. De ahí el extraordinario crecimiento de la población durante los últimos cuatro decenios.

Constituye este fenómeno otro rasgo de especificidad periférica. Agrava a veces con gran intensidad el problema de la insuficiente acumulación de capital, tanto en lo que atañe a la absorción de fuerza de trabajo como a las inversiones que se requiere realizar antes de que esta última alcance la edad productiva.

\section{Pobreza y estructura productiva}

Las consideraciones antes formuladas acerca de la agricultura, nos ayudan a comprender el problema de la pobreza en el contexto general del desarrollo: otro rasgo de especificidad periférica. Pues la pobreza rural se manifiesta en forma impresionante, así como entre los grupos sociales desplazados hacia las ciudades.

Frente a este problema de la pobreza, estamos presenciando cierta efervescencia en torno a una de esas fórmulas seductoras que, esta vez, no brota de nuestra exuberancia insustancial de economistas subdesarrollados, sino de ciertas tierras nórdicas, a mi juicio tal vez erróneamente. Desde allí se nos recomienda ahora 
con celo apostólico combatir la pobreza y satisfacer las necesidades básicas de la colectividad. ¡Se ha descubierto un tanto tardíamente la pobreza del mundo en desarrollo y se nos demuestra que este execrable fenómeno social también existe en nuestras tierras!

Ignórase, desde luego, a la CEPAL, y no sé en verdad si es preferible ignorarla que atribuirle lo que jamás dijo o propuso, como suele hacerse con frecuencia. Se desconocen sus trabajos en los centros, o se los conoce de segunda o tercera mano, manos no siempre bien inspiradas, y frecuentemente desdeñosas de nuestras formas de pensar. De mucho tiempo atrás la CEPAL viene señalando la persistencia de la pobreza y la necesidad ineludible de elevar el ritmo de acumulación para emplear los estratos inferiores con creciente productividad y mayores ingresos. ${ }^{8}$ En otros términos, preconizó la distribución dinámica del ingreso, según lo explicamos en otro lugar.

Sucede, sin embargo, que quienes se proponen desarraigar la pobreza presentan generalmente su fórmula sin enunciar explícitamente la manera de aplicarla. ¿Se trata de una redistribución simple y directa? ¿Podría resolverse el problema de la equidad social sin tocar el sistema? Compréndese que esto último sea realizable en países donde se ha logrado al cabo de mucho tiempo una gran acumulación de capital, en contraste con las dimensiones relativamente reducidas de la pobreza. Pero en los países periféricos, donde esos términos son notoriamente diferentes, no cabría eludir la necesidad de elevar con la mayor intensidad posible el ritmo de acumulación. Y ya sabemos que, más allá de cierto límite, ello no es compatible con la dinámica de la sociedad privilegiada de consumo.

Si se trata, por el contrario, de una redistribución dinámica, si se reconoce la necesidad de una transformación del sistema, habrá que decirlo, y decirlo lisa y llanamente. Y no parecería ser este el caso.

Como quiera que fuere, el ingenio de los promotores de esta fórmula se dedica sobre todo a discurrir acerca de qué necesidades han de satisfacerse para eliminar la pobreza. Y es claro que ya por esta senda generosa, la euforia va muy lejos, hasta compilar una extensa lista de necesidades básicas del género humano y no solamente las inherentes a la pobreza.

Reconozco, sin embargo, que acercándose algo más a los hechos tangibles, algunos admiten la necesidad de cambios en la estructura productiva. Pero no se pasa de esto, imaginando tal vez que esos cambios

${ }^{8}$ Hacia una dinámica del desarrollo latinoamericano, México, Fondo de Cultura Económica, 1963. sobrevendrán de alguna manera sobre todo si el Estado asume la responsabilidad de aquella.

Me excuso, sin embargo, por no presentar aquí un capítulo elocuente acerca de las necesidades básicas. Algún ingenio tendría yo también para hacerlo; pero he preferido emplearlo, tal vez por ser el mío escaso, en la crítica del sistema y su posible transformación.

Por lo demás, sostengo que las necesidades individuales no debieran regimentarse, porque la regimentación significa, fatalmente, imposición autoritaria. He manifestado en otro lugar mi preocupación al respecto. Y ahora, más que nunca, me domina el concepto primordial de libertad del individuo, con el solo límite de no invadir la libertad de los otros, pero en el contexto de un nuevo sistema.

Pienso a veces, y discúlpeseme cierta suspicacia, que algunos de quienes, desde los centros, ofrecen esas fórmulas a la periferia lo hacen para eludir los problemas del nuevo orden económico internacional. ¿Por qué escuchar toda esa retórica perturbadora de la periferia en vez de atacar directamente la pobreza? ¿No sería más fácil cederle para ello algunos recursos financieros?

Sería injusto, sin embargo, sostener que todos piensan así. Hay quienes creen sinceramente en esta solución del problema de la pobreza. Mientras otros, sin caer en ilusiones, consideran que solo así, utilizando la imagen de la desnutrición, las enfermedades y la ignorancia de la periferia, se podrá despertar el adormecido sentido ético de los centros.

Supóngase por un momento que con esa magia benévola pudiera desarraigarse la pobreza sin necesidad de acumular más capital para absorber con creciente productividad los estratos inferiores. En el mejor de los casos se habrían corregido precariamente las tendencias excluyentes del sistema, pero no sus tendencias conflictivas. Antes bien, estas últimas podrían agravarse.

Por cierto que hay países afortunados con otra magia en sus manos: abundantes recursos financieros provenientes de su riqueza natural agotable. Si en vez de disipar esos recursos en la sociedad privilegiada de consumo se dedicaran en la mayor medida posible a la acumulación cabría atacar con eficacia al problema de la pobreza. Y una más alta proporción del excedente podría dedicarse a satisfacer las presiones de consumo inmediato. Sin embargo, ya está visto y comprobado que la opulencia, y no solamente la escasez de recursos, suele perturbar la racionalidad del desarrollo.

Conviene tener siempre a la vista la distinción, tan importante, entre las tendencias excluyentes y conflictivas del sistema. Pues la crisis de este no proviene tanto de la presión de los estratos inferiores con escaso 
o ningún poder redistributivo, sino de los estratos intermedios que han ido adquiriendo una creciente aptitud para compartir el excedente. Es claro que si también adquieren poder redistributivo aquellos estratos inferiores, se acentúa la intensidad de la espiral con todas sus consecuencias.

Hay, pues, dos males que atacar, dos males estrechamente ligados entre sí que no admiten arbitraria segregación. Sin embargo, unos ponen toda su atención en la pobreza y otros en la espiral; todo depende del cristal con que se mira. $\mathrm{Y}$ unos y otros se abstienen generalmente de penetrar en las raíces profundas de esos males. Sospecho que si lo hicieran, no podrían escapar a la conclusión irrecusable de que hay que transformar el sistema.

\section{Especificidad $y$ transformación}

A la luz de lo que acabamos de exponer sucintamente siguiendo nuestros trabajos, se justifica este afán de explorar nuevas vías en el desarrollo periférico.

Nos hemos apartado decididamente de las enseñanzas neoclásicas; y no encontramos en la teoría marxiana la clave de nuestra transformación. Para aquellas el problema de la acumulación se resuelve espontáneamente en el juego irrestricto del mercado. Y para Marx la acumulación era un resultado espontáneo y automático del desarrollo capitalista. La periferia no entraba en su horizonte intelectual.

Acumular deliberadamente por obra del Estado ha sido, sin embargo, una preocupación dominante en la praxis del socialismo de Lenin y Mao. Un socialismo basado fundamentalmente en la socialización y gestión por el Estado de los medios productivos. Hubo en ello autenticidad, en respuesta a un designio de llegar a un socialismo acorde con las condiciones objetivas de una realidad diferente de la que suponía la crítica marxiana al capitalismo. Pero sobre fundamentos políticos muy distintos de los que quisiéramos en esta parte del mundo.

Hay también una necesidad ineludible de autenticidad en la transformación periférica; por eso precisamente hemos subrayado la especificidad del capitalismo vigente.

Como quiera que fuere, hay que precaverse una vez más de otra ilusión imitativa. Hay mucho que aprender de la experiencia de los demás y aprovecharla para llegar a la síntesis entre socialismo y liberalismo. Esta síntesis sería la respuesta de la periferia a la especificidad de su transformación.

\section{Segunda parte}

\section{VI}

\section{Las relaciones centro-periferia en la transformación}

\section{Significado del capítulo}

No se ha cumplido la ilusión del capitalismo imitativo de la periferia de desarrollarse a imagen y semejanza de los centros; lo hemos demostrado ya en nuestros trabajos. Ni se han ido corrigiendo las grandes disparidades sociales, por el contrario, se han ahondado. Tampoco se ha avanzado en el proceso de democratización: otra esperanza frustrada.

Más aún, el capitalismo que se pretendía imitar se encuentra en una grave crisis que, por su carácter estructural, es mucho más compleja y difícil de superar que la gran depresión de los años treinta. Sus repercusiones sobre la periferia ya han comenzado a manifestarse. Surgen nuevamente problemas pertinaces en nuestras relaciones con los centros, cuestiones a las cuales la CEPAL dedicó preferente atención desde sus primeros escritos.

Parecían haberse esfumado esos problemas durante los largos años de bonanza que preceden a esta crisis de los centros. Fueron años de extraordinario desarrollo en estos últimos y también en la periferia, donde, como tantas veces hemos señalado, ha sido impresionante la prosperidad de la sociedad privilegiada de consumo.

Los centros, y muy particularmente el centro dinámico principal del capitalismo, se vincularon cada vez más estrechamente a este tipo de desarrollo basado en una flagrante inequidad social. Jugaron resueltamente sus 
cartas en su favor. Pero como suele suceder en tiempos de bonanza, se desvió la atención de los problemas de fondo, esto es, de las grandes contradicciones en las relaciones centro-periferia.

No podría continuar ahora repitiéndose esa situación frente a la crisis de los centros. Está evidentemente fuera de nuestro alcance dilucidar la índole de esta crisis, pero hemos querido señalar algunos elementos que en ella intervienen para comprender mejor sus repercusiones periféricas. Lo haremos después de examinar sucintamente los problemas de fondo en las relaciones con los centros.

El capitalismo desarrollado ha sido y sigue siendo centrípeto. Es un mito aquello de su poder expansivo en el ámbito planetario. Por grande que haya sido la iniciativa y el empuje de sus empresarios no ha llevado espontáneamente la industrialización a la periferia, en los tiempos de crecimiento hacia afuera. La industrialización la inició deliberadamente la misma periferia; ha sido una imposición de las crisis de los centros. Y se cumple con gran retardo esta exigencia ineludible de su desarrollo, y ese mismo retardo ha suscitado una serie de problemas derivados de la disparidad de la estructura productiva de la periferia con la de los centros. Atañen primordialmente estos problemas:

- a la tendencia inmanente hacia el desequilibrio exterior que frena el desarrollo periférico;

- a la fragmentación económica de esta última, y

- a las considerables diferencias de poder económico y tecnológico que caracterizan los fenómenos de dependencia periférica bajo la hegemonía histórica de los centros.

Esta crisis de los centros es también la crisis de una ideología de desarrollo que, desde el centro dinámico principal del capitalismo, se ha extendido a la periferia, sobre todo a la periferia latinoamericana. Muy incompleto sería este capítulo si no lo termináramos con algunos comentarios que, sobre ser pertinentes, son oportunos frente a lamentables extravíos y retrocesos de la política de desarrollo y las relaciones con los centros.

\section{El carácter centrípeto del capitalismo}

\section{La industrialización deliberada y las ideas de la CEPAL}

No dejará de sorprender mi afirmación acerca del carácter centrípeto del capitalismo avanzado, pues este, como otros fenómenos del desarrollo, escapan a las teorías convencionales. Se debe, fundamentalmente, a la retención por parte de los centros de los frutos de su progreso técnico. Bien sabemos que estos frutos no se difunden al resto del mundo por la disminución de los precios conforme aumenta la productividad. Para bien o para mal, el desarrollo capitalista habría sido completamente diferente si aquello no hubiera ocurrido.

Como quiera que tales frutos se hayan distribuido internamente, la demanda generada por el crecimiento del ingreso en la dinámica del desarrollo se desenvuelve en los mismos centros, salvo aquella fracción que se dedica a adquirir productos primarios en la periferia. Más aún, los ingresos generados por las correspondientes exportaciones de esta última también se traducen en demanda de bienes industriales de los centros.

Estos bienes industriales se diversifican incesantemente en virtud del progreso técnico y las inversiones correspondientes. No hay incentivo para realizar estas inversiones en la periferia, sino en los mismos centros, donde se desenvuelve el proceso diversificador estimulado por aquel acrecentamiento de la demanda.

De esta manera, cuanto más tiempo transcurre, más aumentan las diferencias de estructura productiva entre centros y periferia, con importantes consecuencias sobre el desarrollo.

Decíamos antes que la industrialización periférica no fue el resultado espontáneo de la expansión capitalista de los centros: en sus comienzos tuvo que recurrirse a ella para producir bienes técnicamente simples que no podían importarse debido a las crisis de aquellos (dos guerras mundiales y la gran depresión entre ambas).

Hasta entonces no convenía, en verdad, al interés inmediato de los centros ni al de los grupos dominantes de la periferia producir internamente bienes que esta importaba a precios inferiores a los que hubiera costado su producción interna.

En aquellos tiempos de crisis que impusieron la sustitución de importaciones no pudo pensarse seriamente en la exportación de manufacturas; pero cuando iba alcanzando impulso el proceso industrializador se vio claramente la necesidad de hacerlo. Acaso en la CEPAL fuimos los primeros en subrayar esta necesidad. ${ }^{9}$

\footnotetext{
${ }^{9}$ Así, en un trabajo publicado en 1961, se llamó la atención acerca de la "excesiva orientación de la industria hacia el mercado interno", debido a la "política de desarrollo seguida por los países latinoamericanos y la falta de estímulos internacionales para sus exportaciones industriales".

Y se expresaba que "la política de desarrollo ha sido discriminatoria en cuanto a las exportaciones. En efecto, se ha subsidiado -mediante aranceles y otras restricciones- la producción industrial para el consumo interno, pero no la que podría destinarse a la exportación. Se ha desenvuelto así la producción de numerosos artículos industriales de costos muy superiores a los internacionales, cuando pudo habérselos obtenido, con diferencias de costos mucho menores, a cambio de exportaciones de otros artículos industriales que podrían
} 


\section{Renuencia de los centros a aceptar exportaciones periféricas}

En los escritos de la CEPAL se ha reconocido más de una vez la responsabilidad de la periferia por haber concentrado todos sus esfuerzos en la sustitución de importaciones, sin conceder suficiente atención a las exportaciones de manufacturas. Pero al mismo tiempo se subrayaba la responsabilidad de los centros, y se afirmaba que no habría bastado poner a la producción exportable en el mismo pie de igualdad que la producción sustitutiva interna. Se hubiera necesitado medidas que facilitaran en los grandes centros ciertas importaciones industriales provenientes de los países en desarrollo, dando a estos mayor capacidad para importar precisamente aquellos productos donde son mayores las diferencias de costos. Se habría desarrollado así en el campo industrial una conveniente división del trabajo, muy diferente del esquema tradicional de intercambio de bienes primarios por productos industriales.

Sin embargo, ni los centros alentaron las exportaciones de manufacturas de la periferia, ni esta se resolvió emprender una política francamente favorable a las mismas, hasta que el ritmo extraordinario de desarrollo alcanzado por los centros, a medida que avanzaba el decenio de los años sesenta, demostró la posibilidad de hacerlo.

Las consecuencias de la prosperidad de los países avanzados se manifiestan tanto en las exportaciones periféricas de productos primarios como, sobre todo, en las manufacturas. Estas últimas se desenvuelven en algunos casos con gran celeridad y no solo se debilita la política sustitutiva de importaciones, sino que llega a renegarse de ella.

Durante esos años queda encubierta en cierto modo la tendencia centrípeta del capitalismo, pero esta

haberse producido más ventajosamente. Lo mismo podría decirse de nuevas líneas de exportación primaria y aun de líneas tradicionales dentro de ciertos límites relativamente estrechos". CEPAL, Desarrollo económico, planeamiento y cooperación internacional, publicación de las Naciones Unidas, serie conmemorativa del XXV Aniversario de la CEPAL, Santiago, 1973. (Primera versión: 1961), p. 19 y ss.

Y se agrega en otro trabajo, algo posterior, que "la protección ha sido desde luego indispensable en los países latinoamericanos. Pero no se ha otorgado con moderación ni ha habido en general una política trazada racionalmente y con sentido de previsión indispensable para atenuar -si es que no evitar- las crisis de balance de pagos".

Para decir después que "la industrialización cerrada por el proteccionismo excesivo, y así también los aranceles desmesurados sobre ciertos productos agrícolas importantes, han creado una estructura de costos que dificulta sobremanera la exportación de manufacturas al resto del mundo..." R. Prebisch, Hacia una dinámica del desarrollo latinoamericano, México, Fondo de Cultura Económica, 1963. pp. 86-87. no desaparece. En efecto, el gran esfuerzo exportador que desenvuelve la periferia no llega a los centros en la medida exigida por las crecientes necesidades de importación y el pago de servicios financieros.

La periferia apenas participa marginalmente en el caudaloso crecimiento del intercambio industrial de los centros, alentado por una franca política de liberalización. Sus nuevas exportaciones industriales a los centros, realizadas en gran parte por las empresas transnacionales, conciernen principalmente a bienes donde las innovaciones han dejado de serlo gracias a nuevos avances de la técnica, o se limitan a fragmentos de bienes avanzados en aquellas empresas que aprovechan los bajos salarios, pero sin el designio de introducir formas avanzadas de industrialización integral.

Es comprensible que las transnacionales, llevadas espontáneamente por su propio interés, según se dijo ya en otro lugar, prefieran invertir en los mismos centros donde se registran aquellas innovaciones incesantes y donde se concentra una demanda cada vez más diversificada.

Sin embargo, la periferia podría enviar a los centros bienes técnicamente menos avanzados en los cuales va adquiriendo condiciones competitivas, y ha demostrado aptitud para hacerlo por el empeño de sus propias empresas. Pero a estos bienes no ha llegado la política de la liberalización, sino todo lo contrario.

Esto concierne a la etapa presente del desarrollo periférico. Pero esto no significa en modo alguno que dada una nueva política de industrialización no pueda abordarse la producción y exportación de bienes de creciente complejidad técnica. Tal es la dinámica del desarrollo. ${ }^{10}$

De donde una manifiesta paradoja en las relaciones centro-periferia. Se ha liberalizado en la Ronda Kennedy, como así en la Ronda Tokio, aquello donde la periferia no tiene por ahora ventajas comparativas debido a la superioridad técnica y económica de los centros, que se manifiesta sobre todo a través de las transnacionales. Y escapan a la liberalización -defendidos por diferentes formas de proteccionismo- aquellos bienes manufacturados (y también primarios) donde la periferia tiene ventajas comparativas o podría tenerlas fácilmente gracias a sus propias empresas. ${ }^{11} \mathrm{Y}$ surgen

\footnotetext{
${ }^{10} \mathrm{Y}$ esta es la tesis que desenvuelve Héctor Sosa en un trabajo en preparación para esta Revista.

${ }^{11}$ Un informe reciente donde se evalúa la Ronda Tokio, concluye afirmando que los resultados de las rebajas arancelarias fueron muy magros, ya sea estimados por la merma en la recaudación de aranceles que provocaría su reducción, o por el aumento que dichas rebajas habrían provocado sobre las importaciones de los países desarrollados
} 
nuevas manifestaciones de un proteccionismo inveterado en los centros industriales.

Nada importante se ha hecho pues en los centros, durante sus épocas de prosperidad, para alentar las importaciones provenientes de la periferia. Es bien sabido que el régimen de preferencias, logrado tras largos años de negociación, ha resultado tener escasa significación por las serias limitaciones que entraña.

A todo ello se agregan las consecuencias adversas de la crisis por la que aquellos atraviesan. Ha descendido la tasa de crecimiento de las exportaciones periféricas y, a pesar de ser aún relativamente elevada su cuantía, dista mucho de ser suficiente para que el ritmo de desarrollo se eleve nuevamente, si se ha de evitar el agravamiento de las tendencias excluyentes y conflictivas del sistema, con muy serias consecuencias sociales y políticas. Problemas de solución harto difícil si se tiene presente, además, la necesidad de elevar más aún las exportaciones para cubrir el encarecimiento del petróleo sin acudir indefinidamente al endeudamiento exterior.

\section{La disparidad de estructuras productivas}

A fin de comprender cabalmente la índole de estos problemas conviene examinarlos desde el punto de vista de la estructura productiva.

Se ha explicado en otra parte que el desarrollo trae consigo cambios en la composición de la demanda gracias al incremento de la productividad y al ingreso por habitante; para satisfacer esos cambios también hay que modificar la estructura productiva. Y aquí se plantean dos opciones de la mayor importancia: desarrollar la estructura productiva para satisfacer una parte del crecimiento de la demanda mediante el intercambio de exportaciones por importaciones, o producir internamente en vez de importar.

Es evidente que elegir la opción económicamente más conveniente depende, sobre todo, de la actitud de

procedentes de América Latina si ellas hubieran estado vigentes desde 1976. Asimismo, persiste en los centros tanto un escalonamiento tarifario que grava más pesadamente los bienes finales que a las materias primas -en especial minerales, cueros y fibras textiles- como una extensa y enmarañada red de barreras no arancelarias. Por último, si bien los seis Códigos de Conducta y la reforma al propio Acuerdo General otorgan mayor transparencia al comercio internacional, en el fondo solo consagran institucionalmente las prácticas ya aplicadas por los países desarrollados. Véase Pedro Mendive, "Evaluación de los resultados alcanzados en las negociaciones comerciales multilaterales (Ronda Tokio) hasta el 30 de octubre de 1979", CEPAL (documento mimeografiado), enero de 1980; y del mismo autor,* "Proteccionismo y desarrollo. Nuevos obstáculos de los centros al comercio internacional", en Revista de la CEPAL, Santiago, $\mathrm{N}^{\circ} 6$, segundo semestre de 1978. los centros, además de la decisión de política comercial de la periferia.

La actitud de los centros fue naturalmente negativa en los tiempos de crisis que alentaron la industrialización de la periferia. Como ya se ha visto, y no está demás repetirlo, la periferia tuvo que recurrir ineludiblemente a la producción interna sustituyendo importaciones. Y es un hecho plenamente comprobado en los estudios de la CEPAL que, gracias a ello, los países latinoamericanos pudieron tener un ritmo de desarrollo superior al ritmo de crecimiento de sus exportaciones a los centros industriales. El costo más alto de la sustitución fue compensado con creces por el incremento mucho mayor del producto. Tal fue la economicidad de la sustitución, que pudo ser más importante si se hubiese seguido una política más racional como observamos antes.

No digo que sea igual la situación que ahora se le presenta a la periferia a raíz del descenso del ritmo de desarrollo de los centros, tan inferior al de los tiempos de euforia, y a la acentuación del proteccionismo. La periferia ha aprendido a exportar y parte de estas exportaciones van a los centros. Pero como ya expresamos, su cuantía es muy inferior a la requerida, tanto más si se logra acelerar el desarrollo.

Hubo un cambio importante en la estructura productiva, pero el mismo dista mucho de ser suficiente. $\mathrm{Y}$ en la medida en que los centros no admitan más importaciones de la periferia, esta deberá orientar también su estructura productiva para satisfacer mediante la sustitución de importaciones lo que no pueda hacerse mediante el intercambio.

De donde se llega a una conclusión palmaria: en esta crisis, así como en otras más lejanas, los centros han forzado y están forzando a la periferia a sustituir importaciones.

La diferencia con dichas crisis lejanas consiste en que ahora es posible combinar el esfuerzo de la sustitución con el necesario para seguir acrecentando las exportaciones industriales.

Ahora bien, la forma en que se combinan estos esfuerzos depende primordialmente de la actitud de los centros con respecto a tales exportaciones industriales de la periferia. Si el empeño por acrecentarlas encontrara graves obstáculos, tanto por la tendencia centrípeta del capitalismo desarrollado como por los restantes factores adversos ya mencionados, la periferia no tendría otra solución que orientar con más intensidad su estructura productiva hacia la sustitución de importaciones, para no comprimir su propio ritmo de desarrollo o desarrollarse con más intensidad de lo que de otro modo fuera posible. No sabríamos decir si las empresas transnacionales 
pudieran contribuir eventualmente a corregir esa tendencia centrípeta exportando a los centros bienes avanzados; hasta ahora no lo han hecho en magnitudes impresionantes, si bien han desempeñado un papel importante en las exportaciones a países periféricos. Y podrían tenerlo mucho más aún si la sustitución se cumpliera en el ámbito regional, punto este sobre el que volveremos oportunamente.

Este hecho, y la succión de ingresos periféricos, explican que las transnacionales, si bien contribuyen primero a corregir el desequilibrio externo con la sustitución de importaciones, tienden después a acentuarlo en las relaciones con los centros cuando la transferencia de sus ganancias y otros pagos desde el exterior excede sus nuevas aportaciones de capital, al mismo tiempo que se van agotando las posibilidades de nuevas sustituciones.

A estas formas de succión de ingresos se agregan otras que provienen de la superioridad técnica y económica de los centros y la gravitación de su poder político.

Como bien sabemos, las disparidades de la estructura productiva tienen su origen en el retardo del desarrollo periférico debido a la tendencia centrípeta del capitalismo de los países avanzados. Dos puntos importantes conviene destacar a este respecto.

El primero concierne a la elasticidad ingreso de la demanda por parte del centro de importaciones primarias de la periferia. Esta elasticidad es relativamente baja, salvo algunas excepciones. Y el empeño de la periferia, en los tiempos de crecimiento hacia afuera, de acrecentar sus exportaciones más allá del límite impuesto por el desarrollo de los centros estaba -y sigue estando- expuesto al deterioro de la relación de precios.

A esta debilidad congénita de las exportaciones primarias se agrega su gran vulnerabilidad exterior, como que los movimientos cíclicos de los centros se transmiten a aquellas con más intensidad que en estos.

La baja elasticidad ingreso se manifiesta asimismo en la producción primaria de los mismos centros. Y los ha llevado a restringir deliberadamente la producción, como en los Estados Unidos, o a restringir las importaciones, como en la Comunidad Económica Europea. Como la periferia no tiene esas posibilidades, la tendencia al deterioro ha llevado a frenar la producción, casi siempre espontáneamente en perjuicio del mayor excedente que pudo haberse logrado si el fruto del progreso técnico hubiera podido retenerse en mayor proporción en la periferia.

En consecuencia, en aquellos tiempos de desarrollo hacia afuera y en la medida en que los centros no admitían con liberalidad exportaciones industriales de la periferia, solo cabía la producción sustitutiva interna para desarrollarse. No había otra forma de contrarrestar la tendencia hacia el desequilibrio externo provocado por la gran diferencia entre esa elasticidad ingreso relativamente baja de la demanda en los centros de exportaciones primarias de la periferia, según se anotó poco antes, y la elasticidad ingreso relativamente alta de la demanda de exportaciones industriales provenientes de los centros en la periferia y sujetas incesantemente a la diversificación.

Es este un fenómeno transitorio del desarrollo; pero se trata de una transición que requiere un tiempo prolongado. Se concibe, en efecto, que las mutaciones de la estructura productiva de la periferia permitan acercarse progresivamente a un equilibrio exterior de carácter estructural. Ello depende, en última instancia, de la actitud favorable de los centros y de la sustitución de importaciones en el ámbito latinoamericano, así como del intercambio con otros países periféricos.

No faltan por cierto economistas en los centros que, aun dejando de lado estos fenómenos estructurales de las relaciones centro-periferia, señalan las ventajas de realizar importaciones de bienes menos avanzados pagándolas con exportaciones de bienes avanzados de gran productividad por hombre. Pero no bastan estas consideraciones racionales para que puedan adoptarse decisiones políticas que modifiquen tanto la estructura productiva de los centros como la de la periferia. Más aún, durante esos años de extraordinario desarrollo de los países avanzados, el desempleo de la fuerza de trabajo que pudo haber ocurrido en las industrias perjudicadas por la competencia periférica habría podido compensarse con el empleo en aquellas otras industrias y actividades de intenso crecimiento. Se ha preferido, sin embargo, emplear trabajadores de otros países menos desarrollados, lo cual ha probado posteriormente tener también alguna racionalidad, aunque no muy humana: despedirlos y repatriarlos cuando se redujo el ritmo de desarrollo.

\section{Las ventajas comparativas}

A la luz de estas consideraciones, habría que reexaminar ciertas tesis que, como la de las ventajas comparativas y la reciprocidad del intercambio, suelen presentarse nuevamente sin referencia a las grandes disparidades en la estructura productiva entre centros y periferia.

Frente a los fenómenos del capitalismo centrípeto y su renuencia a liberalizar aquellos bienes industriales donde la periferia tiene estas ventajas comparativas, no 
le resta a esta última otra solución que sustituir importaciones. Ahora bien, esta sustitución debe responder a consideraciones de economicidad. ¿Cómo podrían seguirse estas consideraciones? Desde luego, y sobre todo durante una cierta fase inicial, la producción sustitutiva interna representa un mayor costo que las importaciones, esto es, una desventaja comparativa. Pues bien, esas consideraciones de economicidad aconsejan sustituir aquellos bienes donde sea menor la desventaja comparativa. Entiéndase bien: desventaja directa, pues como se expresó oportunamente, esta desventaja se supera con creces con el aumento del producto.

Es muy diferente la situación al respecto, según los países; hay algunos relativamente pequeños donde, por ejemplo, ciertas líneas de sus exportaciones agrícolas podrían desenvolverse sin detrimento de su relación de precios, sobre todo cuando se trata de bienes que, por sus condiciones particulares, tienen sostenida demanda en los centros. También hay ciertos bienes industriales que poseen esa particularidad.

Casos semejantes pueden darse asimismo en países de mayores dimensiones, pero no hay razones para pensar que ello tenga carácter general, y que esas exportaciones basten para lograr un ritmo de desarrollo suficiente para resolver las fallas del tipo de desarrollo prevaleciente.

\section{La reciprocidad en el intercambio}

Si bien los centros no reconocen las ventajas comparativas de la periferia, hay allí quienes vuelven a oponerse a la sustitución de importaciones, y esgrimen la vieja tesis de reciprocidad en el intercambio. Según esta tesis, cualquier liberalización de las importaciones provenientes de la periferia debería acompañarse aquí de una liberalización similar de las importaciones provenientes de los centros. Sigue desconociéndose la tendencia al desequilibrio exterior del desarrollo periférico provocada por la disparidad de elasticidades. Y lo más grave es que estas ideas, que pudieran haberse considerado superadas por el esclarecimiento de los fenómenos del desarrollo, dominan de nuevo en ciertos sectores de nuestros países. ${ }^{12}$

\footnotetext{
12 Parece oportuno, pues, recordar lo que dijimos en 1963:

"Los países periféricos están en posición diametralmente opuesta a la de los centros en materia de reciprocidad en el intercambio. Estos exportan manufacturas cuya demanda tiende a crecer en forma intensa con el crecimiento del ingreso periférico; en tanto que aquellos exportan productos primarios que tienden a crecer con lentitud con el ingreso de los centros".

"En consecuencia, los centros no necesitan sustituir importaciones desde este punto de vista, pues el desequilibrio comercial con la periferia
}

Frente a estas ideas de la CEPAL, que no han perdido en forma alguna su vigencia, es sorprendente que en América Latina se haya llegado a rebajar aranceles y exponer industrias a la competencia destructiva del exterior, a la espera de que los centros decidan practicar la reciprocidad liberalizando las importaciones provenientes de la periferia. ¡Mucho me temo que esta espera se prolongará indefinidamente!

Todo esto es harto conocido en el seno de la CEPAL. Y si lo recuerdo ahora, es para acercar a la realidad a algunos de nuestros economistas que viven en un mundo aséptico donde incuban sus doctas elucubraciones. Discurren así sobre internacionalización de la producción y apertura exterior. ¡Excelente, pero que los centros comiencen primero! Largos años de lucha, principalmente en la UNCTAD, no lograron modificar la actitud restrictiva de los centros. ¿Creen acaso que podrán conmoverlos con el espectáculo de industrias que cierran debido a la apertura exterior?

Que hay ciertas industrias que deben aumentar su productividad o desaparecer, no cabe duda alguna; trátase de industrias que por su considerable desventaja comparativa no debieran haberse establecido. Pero sería un grave error desbaratarlas mientras una mayor acumulación de capital reproductivo y la elevación del ritmo de desarrollo no permita reabsorber el desempleo.

tiende a ser positivo, esto es, a un exceso de exportaciones".

"En cambio, la tendencia al desequilibrio negativo en los países periféricos les impone la sustitución dentro de las pautas presentes de intercambio para evitar el déficit en el balance de pagos".

"Más aún, si los centros, por otras razones justificables o no, sustituyen importaciones provenientes de los países periféricos, agravan esa disparidad de la demanda internacional. En cambio, la sustitución de importaciones provenientes de los centros en los países periféricos, tiende a corregir la disparidad para hacer posible el desarrollo.

"Esta desigualdad fundamental exige la revisión del concepto hasta ahora vigente de reciprocidad, pues si los centros, reducen o eliminan sus aranceles, los países periféricos podrán aumentar sus exportaciones a ellos. Y al suceder así, también acrecentarán sus importaciones, en virtud de la intensa demanda que para ellas existe."

"Exigir a un país en desarrollo concesiones arancelarias equivalentes significaría lesionar su industrialización en claro desmedro de su desarrollo económico".

En seguida se aclaraba que la idea de reciprocidad implícita no suponía que se dejara de lado la corrección de los abusos del proteccionismo. Todo lo contrario... "es necesario rebajar en forma gradual los aranceles frente al resto del mundo, guiándose por conceptos de economicidad, y a fin de que la industria se vea continuamente estimulada por la competencia exterior a reducir sus diferencias de productividad con los grandes centros".

"Es claro que una reforma de esta naturaleza no podría cumplirse en condiciones de estrangulamiento progresivo. Antes tiene que venir el alivio exterior, la aceleración del ritmo de las exportaciones. En otros términos, la racionalidad de la tarifa arancelaria tiene que ser parte de un plan internacional de expansión de intercambio sobre nuevas bases. No podrá adelantarse a esta política, sino ser consecuencia de ella." Téngase en cuenta que esto se decía antes de la UNCTAD. Hacia una dinámica del desarrollo latinoamericano, op. cit., pp. 89 y ss. 
Es un problema de oportunidad y tiempo. Primero hay que hacer avanzar la estructura productiva, sea para exportar o para sustituir importaciones, ateniéndose a las ventajas o desventajas comparativas; y después abordar el reajuste a fondo de la protección abusiva. No destruir hasta poder construir mejor.

\section{La fragmentación económica de la periferia}

En los centros el cambio en la estructura productiva ha sido enérgico y continuo. Pero ningún país ha pretendido producir intensamente todo lo que exigían las mutaciones incesantes de la demanda; por el contrario, se ha dividido el trabajo entre los distintos países avanzados desenvolviendo en forma extraordinaria el intercambio, alentado por incesantes innovaciones tecnológicas. Tal ha sido el significado dinámico de las dos rondas de liberalización que ya mencionamos.

Sin embargo, los países periféricos no han sabido establecer formas racionales de división del trabajo entre ellos. En la medida en que no les ha sido posible exportar suficientemente a los centros, cada país ha desenvuelto su producción industrial con prescindencia del intercambio con los restantes. Es indispensable por ello que la sustitución se cumpla en el ámbito latinoamericano.

Desde los primeros escritos de la CEPAL, a comienzos de los años cincuenta, y antes del Mercado Común Europeo, hemos llamado la atención acerca de la tendencia al agotamiento de las sustituciones fáciles y la necesidad de pasar a una producción técnicamente más compleja y que exigía mercados mucho más amplios que los compartimientos estancos de los diferentes países.

Surgió así la idea del mercado común latinoamericano, basado tanto en la reducción progresiva de aranceles y otras restricciones, como en acuerdos de especialización industrial concertados por los gobiernos.

La idea del mercado común fue resistida inicialmente por los centros, sobre todo por los Estados Unidos. Influidos por sus intereses inmediatos, no supieron advertir la significación dinámica de esta iniciativa latinoamericana.

Terminaron finalmente por aceptarla, pero oponiéndose a la especialización concertada, pues esta privaba a las empresas transnacionales de la libertad de decidir lo que mejor se acordaba a sus intereses.

Me inclino a creer que este ha sido un factor adverso, pero lo que más ha influido en el desaliento de la marcha hacia el mercado común fue aquella euforia del intercambio provocado por el ritmo extraordinario de desarrollo de los centros. No solo me refiero al intercambio de la periferia con estos últimos, sino al intercambio entre los diferentes países periféricos, fuertemente estimulado por las repercusiones de aquel otro proceso.

Vuelve a plantearse ahora el mismo problema de sustitución de importaciones en el ámbito latinoamericano. No creo en forma alguna que tenga que recurrirse a las fórmulas originarias: ¡ Ha pasado mucha agua bajo los puentes! Hay que extraer enseñanzas de la experiencia y llegar a fórmulas que, entre otros aspectos, aseguren la distribución equitativa de ventajas, tanto para los países más desarrollados como para los menos desarrollados y los de mediano desarrollo.

Es necesario superar la fragmentación económica de nuestros países. Es esta otra de las manifestaciones del retardo histórico de su desarrollo provocado por la índole centrípeta del capitalismo; cada país periférico convergía separadamente de los otros en el abastecimiento de productos primarios. Y cuando sobrevino la industrialización como consecuencia de las crisis de los centros, no supimos romper el viejo esquema centroperiferia con una división racional del trabajo.

Este esquema sigue vigente en gran parte en las relaciones entre nuestros países. Se impone cambiarlo ahora que se ha disipado nuevamente el mito de la expansión indefinida del capitalismo. Más todavía, aunque los centros siguieran una política más favorable hacia las importaciones periféricas, mal podríamos volcar sobre ellos todas las exportaciones que se requiere para satisfacer las exigencias dinámicas del desarrollo y la transformación del sistema.

\section{Hegemonía y dependencia}

El retardo con que comienza el desarrollo integral de la periferia -basado en la industrialización- se manifiesta notoriamente en la superioridad económica y técnica de los centros, sobre todo del centro dinámico principal del capitalismo. $\mathrm{Y}$ esta superioridad trae consecuencias económicas y políticas que conviene distinguir, si bien ambas están estrechamente relacionadas, y se desenvuelven bajo el signo hegemónico de aquellos.

Esta hegemonía se manifiesta en distintas formas y grados sobre los países periféricos, en el empeño de los centros por promover y defender sus intereses económicos, políticos y estratégicos. Y en el ejercicio directo de esa hegemonía los centros tienen instrumentos poderosos: la cooperación financiera, económica y tecnológica, así como la ayuda militar. 
Las transnacionales, además de sus propios objetivos, suelen ser agentes eficaces en esa hegemonía. Los centros promueven su penetración en diferentes ramas de la actividad interna de la periferia; y las transnacionales, a su vez, sostienen en una u otra forma aquellos intereses hegemónicos. En lo que concierne a sus propios intereses, las transnacionales tienen una doble influencia. La tienen en los centros y en la periferia sobre los medios masivos de difusión social, sobre los movimientos políticos que sustentan el sistema y sobre los gobiernos. Y en los centros hay, además, toda una constelación de intereses que gravitan sobre la periferia y sus gobiernos.

Todo esto configura las consabidas relaciones de dependencia con diferente intensidad según la aptitud de los países para defender su autonomía. La dependencia lleva a hacer a un país periférico lo que de otro modo no haría, y a dejar de hacer lo que de otro modo haría. Y la capacidad de negociación es limitada.

Nunca aparece más notoriamente la dependencia que cuando un país periférico menoscaba el interés hegemónico de los centros, sobre todo el centro principal. Se mueve entonces contra aquel toda aquella constelación de intereses y sobrevienen, en una u otra forma, medidas punitivas que en el pasado -nada lejano por cierto- desembocaron en operaciones militares.

Hay economistas y sociólogos que extienden el concepto de dependencia a todas las relaciones centroperiferia. No habría nada que objetar si examinaran con claridad las diferentes consecuencias de la índole centrípeta del capitalismo, como hemos tratado de hacerlo en páginas anteriores. Pero con frecuencia no sucede así; por ello nos hemos esforzado en este esclarecimiento, a riesgo de repetir lo dicho en otros trabajos.

Más aún, se ha llegado a sostener que la dependencia, como quiera que se la interprete, es responsable del subdesarrollo. Traducido esto a nuestro lenguaje, significa que la pobreza de las grandes masas excluidas del desarrollo habría sido generada por la acción de los centros.

Nada se gana en el campo de la teoría, como así tampoco en el de la praxis, con este género de afirmaciones, lo cual no significa negarles eficacia en el adoctrinamiento político.

Hay que distinguir entre la existencia de la pobreza y su persistencia. Cuando comienza a penetrar la técnica de los centros en las actividades exportadoras de la periferia, gran parte de la población se encontraba en la pobreza, y esta ha ido disminuyendo conforme la técnica penetra más allá de aquellas actividades. Pero los frutos de la técnica, en vez de capitalizarse plenamente, impulsan a la sociedad privilegiada de consumo y a la succión de ingresos por parte de los centros, de manera que aparece la tendencia excluyente del sistema, cuya explicación huelga repetir aquí. De donde la persistencia de la pobreza, acentuada por el intenso crecimiento demográfico.

Los centros y sus relaciones de dependencia no crean la pobreza, pero sí contribuyen a hacerla perdurar, debido a la índole centrípeta del capitalismo. Podría decirse que ello ocurre precisamente por no cumplirse el mito de la expansión planetaria de aquel. Por cierto que, si se hubiese hecho realidad este mito, lo hubiera sido en gravísimo desmedro de la autonomía periférica, por precaria que ella fuese ahora.

Tampoco han faltado en la periferia quienes creyeron que las empresas transnacionales podrían realizarlo. Pero bien sabemos que no ha ocurrido así, debido a las mencionadas tendencias centrípetas del capitalismo. Como llevamos dicho, en el plano internacional no hay factores que lleven espontáneamente a contrarrestar tales tendencias. Las transnacionales tienen otro horizonte y no podría esperarse de ellas que cambien por sí mismas de actitud para ayudar a la periferia a profundizar la penetración de la técnica en su estructura social.

¿Pero acaso lo está haciendo la misma periferia? ¿Acaso está empleando a fondo el potencial de acumulación de capital proveniente de su progreso técnico para absorber con creciente productividad los estratos inferiores que vegetan en la indigencia? No lo permite el interés de quienes disfrutan de la sociedad privilegiada de consumo.

He ahí una conclusión terminante: el simple juego del interés privado, por legítimo que fuese, no podría transformar la dinámica limitada de la sociedad privilegiada de consumo ni la índole centrípeta del capitalismo. Trátase, en el fondo, de problemas en gran parte estructurales que requieren grandes decisiones políticas así en los centros como en la periferia.

Sin embargo, los centros atraviesan por una crisis que hace mucho más difícil tomar estas decisiones; y otro tanto ocurre en la periferia. Trataremos, en la parte siguiente, de destacar, pues, los principales elementos de esta crisis. 


\section{VII}

\section{La crisis del capitalismo en su centro dinámico principal y sus repercusiones sobre la periferia}

\section{Una primera visión}

La crisis presente del capitalismo es muy compleja, y más difícil de resolver que la gran depresión de los años treinta.

Trátase, a mi juicio, de una crisis provocada por el mismo vigor del capitalismo. Este se ha salido de madre, ha desbordado sus propios cauces, y no ha encontrado aún cómo recuperar la regularidad de su desarrollo.

He tratado de comprender estos fenómenos que, además de la enorme importancia que revisten para los centros, repercuten intensamente sobre la periferia. Es la mía una interpretación desde esta última, vista a la distancia, y expuesta a errores que, así lo espero, no sobrepasen a los que suelen cometer quienes, desde los centros, dictaminan desprevenidamente sobre la periferia.

Antes de los trastornos de los últimos tiempos, ha habido un extraordinario aumento de la productividad y el producto global en los Estados Unidos, cuyas consecuencias se difundieron internacionalmente. Este hecho, sin embargo, encerraba un elemento de falsedad, pues esa productividad se había logrado en gran parte gracias a técnicas depredatorias de recursos naturales agotables y que, además, traían consigo un grave deterioro del medio ambiente. Se ha estado consumiendo el capital natural de la biosfera.

Exigencias crecientes de consumo, inversión y gastos del Estado acompañaron a ese aumento del producto, sin que en su asignación hubiera un criterio de compatibilidad. Más aún, en gran parte por la inflación provocada por los gastos del Estado, tales exigencias han superado el crecimiento del producto, y se han cubierto a expensas del producto del resto del mundo, a cambio de signos monetarios que han propagado internacionalmente la inflación, y a lo cual han venido a añadirse las consecuencias del encarecimiento del petróleo.

La corrección de ese falso elemento en la dinámica del desarrollo requerirá cuantiosas inversiones que, no obstante su positiva significación ecológica y social, no traerán consigo nuevos incrementos de productividad. Descenderá pues la productividad media.

Este descenso va a agregarse al que ya venía registrándose tanto por la evolución orgánica del sistema como por ciertas inversiones que, por su índole y cuantía, venían deprimiendo también la productividad.

El sistema se encuentra ante una realidad incontrastable. Se ha desvanecido la ilusión de una prosperidad lograda en detrimento de la biosfera; y también la ilusión del poderío ilimitado del dólar.

Que el sistema tiene una enorme vitalidad, no cabe duda. Pero sería necesario un período de transición, por ahora indefinido, para introducirle grandes reajustes a fin de superar sus trastornos.

Tendrá que reorientarse la técnica y también la acumulación de capital. Pero acumular capital cuando desciende la productividad plantea un problema nuevo y difícil al desarrollo capitalista. Problema que se agrava si se ha de eliminar la inflación.

Será inescapable la disminución del ritmo de consumo en un país acostumbrado a su incesante expansión. Pero no parecería haber todavía clara conciencia de esta imposición de la realidad.

Mas no es eso solamente. Me pregunto insistentemente si los mecanismos vigentes de acumulación y distribución resultan adecuados a la solución de aquellos problemas. Tanto más cuanto que ya venían manifestándose ciertas perturbaciones en la evolución del sistema.

Vamos a desenvolver ahora las ideas que tan sucintamente se acaban de exponer. ${ }^{13}$

\section{Extraordinaria productividad a expensas de la biosfera}

Es posible ahora ver con mayor claridad que antes en el desarrollo capitalista de los centros. El extraordinario impulso de los últimos decenios hasta tiempos recientes no es solo consecuencia de un impresionante adelanto técnico, sino también de la explotación irracional de recursos naturales, sobre todo del recurso energético que, a su vez, ha influido notablemente en la orientación de la técnica, de donde aquel elemento de falsedad de muy dramáticas consecuencias mundiales.

\footnotetext{
${ }^{13}$ En las páginas siguientes he utilizado parte del trabajo ya citado sobre "Biosfera y desarrollo".
} 
En todo ello ha sido de importancia decisiva el poder hegemónico de los centros en la periferia de la economía mundial, sobre todo el de Estados Unidos. Los países exportadores de petróleo carecían de poder para contrarrestar esa hegemonía, si bien de tiempo atrás tenían clara noción de que este recurso agotable se estaba malbaratando, pero hubieran encontrado grandes resistencias en cualquier empeño por contener esta explotación desorbitada.

Los países exportadores solo pudieron restringir concertadamente el incremento de la producción en una coyuntura internacional que les permitió adquirir poder y enfrentar el poder de los centros.

Si bien se reflexiona, la irracionalidad en la explotación del recurso energético como consecuencia del empleo de nuevas técnicas y del incentivo de ganancias de las empresas petroleras, se propagó a todo el sistema. El bajo costo del petróleo influyó considerablemente en la investigación tecnológica, orientándola hacia formas en extremo abusivas de utilización de este bien agotable, y también de otros recursos naturales. Todo ello, alentado por la distribución desigual del fruto de la creciente productividad de la técnica, dada la índole de la estructura social y sus mutaciones.

Pero no se trata de eso solamente. La investigación tecnológica, hasta tiempos recientes, no se había preocupado de los efectos adversos de la técnica sobre el medio ambiente. Tal es la ambivalencia de la técnica: su enorme contribución al bienestar humano gracias al aumento incesante de la productividad y, a la vez, sus graves consecuencias sobre la biosfera.

Filósofos y humanistas se vienen ocupando desde hace tiempo de las consecuencias psicosociales de la técnica, pero los economistas han sido generalmente renuentes a insertar su ambivalencia en la interpretación de los fenómenos del desarrollo. La han considerado elemento exógeno, como a los elementos políticos, sociales y culturales de la realidad. Preocupados por una peculiar asepsia doctrinaria, se han resistido a la inserción de estos elementos, y de las mutuas relaciones que existen entre ellos, en la dinámica del desarrollo.

\section{Exigencias incompatibles con el crecimiento del producto}

Decíamos que no obstante el crecimiento extraordinario del producto, este no había sido suficiente para responder a exigencias que competían entre sí para captar una parte creciente de aquel en el centro dinámico principal del capitalismo. Se trata de la creciente magnitud de las inversiones internas y extranjeras, del gran impulso al consumo privado y de la expansión considerable de los servicios del Estado, entre ellos los servicios sociales y los gastos militares.

Este incremento de los gastos del Estado ha sido en gran parte inflacionario. El Estado, por comprensibles razones políticas, ha sido renuente al aumento de impuestos, y ha tenido que recurrir a la expansión monetaria para cubrir el déficit fiscal. Sin embargo, de haberlo hecho, las consecuencias también hubieran sido en gran parte inflacionarias. En efecto, si los impuestos hubiesen recaído, en una u otra forma, sobre la fuerza de trabajo, esta hubiera tratado de resarcirse mediante el aumento de sus remuneraciones en desmedro del excedente económico, y ello habría traído consigo el alza de precios. Las empresas se habrían defendido en la misma forma si los impuestos hubieran gravado directamente al excedente, en menoscabo de la acumulación de capital.

Como quiera que fuere, el financiamiento inflacionario del déficit ha provocado el alza de los precios; y el reajuste siguiente de las remuneraciones ha acentuado considerablemente la espiral inflacionaria que ya venía desenvolviéndose en forma moderada. $\mathrm{Y}$ a todo ello se agrega el nuevo impulso inflacionario provocado por la crisis energética y la defensa del medio ambiente.

Sin embargo, estas diferentes presiones se han aliviado gracias a que una parte de la expansión inflacionaria de la demanda debida al déficit fiscal ha podido satisfacerse con el incremento de las importaciones, esto es, a expensas del producto bruto del resto del mundo. En las dimensiones de este hecho, agravado con el aumento de las importaciones de petróleo y su considerable recargo de valor, ha influido de manera considerable la distribución regresiva del ingreso que ha acompañado a la inflación. En efecto, ha crecido intensamente la importación de aquellos bienes hacia los cuales se orienta con preferencia la demanda de los grupos sociales favorecidos por la inflación, sobre todo en detrimento del consumo de los grupos sociales de menor poder redistributivo y defensivo.

Este crecimiento de las importaciones por sobre las exportaciones y otros recursos exteriores, ha sido el factor más importante en el déficit crónico del balance de pagos de los Estados Unidos. Además de ello, cabe agregar las inversiones de las transnacionales en el exterior, en la medida en que no fueron cubiertas con sus propias ganancias externas.

Expresado esto en otra forma: la expansión de los gastos del Estado no se ha cubierto en detrimento del consumo -salvo el consumo de los grupos sociales perjudicados-, sino que se ha superpuesto a él y a las 
inversiones privadas. Y el exceso consiguiente de la demanda en relación al producto interno ha desbordado hacia afuera, y se ha satisfecho con importaciones.

\section{Descenso orgánico de la productividad}

Para comprender el descenso de la productividad que acontece en el curso avanzado del desarrollo capitalista, debe tenerse en cuenta las dos manifestaciones donde aquella se presenta: las innovaciones tecnológicas que se incorporan continuamente al sistema, por un lado, $\mathrm{y}$, por el otro, el aumento de productividad que ocurre por el desplazamiento de fuerza de trabajo de ocupaciones de menor productividad a otras de superior productividad.

Conforme crece la acumulación de capital en bienes físicos y formación humana, va disminuyendo progresivamente la proporción de fuerza de trabajo empleada con inferior productividad. Dicho de otro modo, hay una tendencia a la homogeneización de la técnica y de la productividad, con efectos importantes sobre los ingresos.

Ahora bien, a medida que se opera esta tendencia, habrá un descenso en la productividad media del sistema si no aumenta el ritmo de la productividad de la nueva acumulación que exigen las innovaciones. Tendría que elevarse este ritmo para compensar el efecto de la homogeneización de la técnica.

Pero hay algo más de mucha importancia. Como se ha explicado en otro lugar, el aumento de la productividad proveniente de la acumulación de capital reproductivo, estimula la diversificación incesante de bienes y servicios mediante la acumulación de capital consuntivo. Se trata de técnicas que, si bien no aumentan la productividad, mejoran la eficacia y la aptitud de los bienes para responder a nuevas necesidades o a consideraciones de jerarquía social y consumo conspicuo.

Estas técnicas, así como la acumulación correspondiente, se combinan estrechamente desde luego con las de productividad, pero a medida que ello acontece, va aumentando la proporción de capital consuntivo en menoscabo del capital reproductivo. Tal es una consecuencia lógica de la evolución orgánica del sistema: no tendría sentido aumentar la productividad acrecentando continuamente la disponibilidad de los mismos bienes y servicios, pues es evidente que ello disminuye el ritmo de la productividad.

En consecuencia, el ritmo de la productividad media disminuye tanto por los efectos de la homogeneización de la técnica sobre el desplazamiento de la fuerza de trabajo, como por una proporción cada vez mayor de la fuerza de trabajo que así se desplaza y dirige, con la correspondiente acumulación de capital, a satisfacer la tendencia cada vez más intensa de la demanda por la diversificación de bienes y servicios en que se acrecienta más la eficacia que la productividad.

Suele decirse a veces que el descenso de la productividad media se debe a que sube cada vez más la proporción de los servicios calificados en relación a los bienes. Es correcto, pero no es suficiente para explicar este fenómeno. Pues, como se acaba de ver, también sube la proporción de los bienes que se diversifican y en los cuales la técnica mejora su eficacia más bien que su productividad.

Se expresó más arriba que la diversificación es una consecuencia de la creciente productividad del sistema; pero también tiene considerable influencia la distribución del fruto de la productividad. Así pues, los estratos sociales favorecidos por la distribución tienden a acrecentar la demanda de bienes y servicios diversificados mucho más intensamente que los estratos desfavorecidos, cuya demanda se concentra en bienes de escasa diversificación. Este fenómeno se acentúa con los efectos regresivos de la inflación y agrava el descenso de la productividad media del sistema.

Finalmente, hay que añadir a todo esto un factor muy importante: la acumulación de capital para producir armamentos. Es obvio que esta acumulación contribuye también en el descenso de la productividad media, aunque no hay que olvidar, sin embargo, que las innovaciones en la técnica armamentista han tenido gran influencia en otras innovaciones del sistema.

Si abundamos al respecto, aunque en forma un tanto esquemática, es porque tiene gran importancia para comprender la incidencia del descenso de la productividad sobre el excedente económico, en donde se encuentra la clave dinámica del sistema, y también para abarcar la complejidad de los grandes reajustes exigidos por la crisis de este último, sobre todo en el centro principal del capitalismo.

\section{Excedente y descenso de productividad}

En el examen del capitalismo periférico hemos atribuido primordial importancia al fenómeno estructural del excedente que también se ha presentado en el desarrollo histórico del capitalismo de los centros. Pero en estos, aquella tendencia a la homogeneización que antes señalamos, va estrechando el excedente formado por sucesivos aumentos de productividad. Cuanto más intensa es esta tendencia y disminuye tanto más la proporción de fuerza de trabajo en técnicas inferiores, 
más se fortalece su aptitud espontánea para mejorar sus remuneraciones.

Pero, al mismo tiempo, ha ido desenvolviendo su poder sindical y político, de manera que acrecienta cada vez más su presión sobre el excedente. Asimismo, el intenso desenvolvimiento de los servicios del Estado también presiona, directa o indirectamente, sobre el excedente. Este último está pues sujeto a dos movimientos opuestos. Por un lado, nuevos incrementos de productividad y, por otro, esa doble presión del Estado y de la fuerza de trabajo. Nada hay en el sistema que regule esta doble presión.

Siendo ello así, se llega a una fase de la evolución del sistema en que esa doble presión impide al excedente, sobre todo el de los estratos superiores de la estructura social, cumplir su papel dinámico. Pues esa doble presión se cumple en detrimento de la acumulación de capital y el consumo de tales estratos, a pesar de nuevos aumentos de productividad. Tarde o temprano, las empresas donde ellos prevalecen suben los precios, a fin de restablecer el crecimiento del excedente o, si se quiere, el de sus ganancias, si se me permite en esta escueta presentación de un complejo fenómeno, identificar las ganancias con el excedente.

Cuando la fuerza de trabajo tiene gran poder sindical y político, como ha ocurrido en los centros, al aumento de precios sigue el de las remuneraciones. Tal es la significación de la espiral inflacionaria.

Me inclino a creer que la espiral que se desenvolvía en los Estados Unidos, antes que alcanzara grandes dimensiones el déficit fiscal, era la consecuencia de estos fenómenos. En la presentación que acaba de verse, hemos preferido sacrificar el rigor a la simplicidad del razonamiento.

\section{Las exigencias de la crisis y el régimen de acumulación y distribución}

Todo indica que el centro principal, así como los otros centros, tendrán un ritmo de crecimiento de la productividad y el producto sensiblemente inferior al de aquellos años de ritmo extraordinario. Habrá pues un período de transición, después de los grandes reajustes que exige el sistema, sobre cuya duración sería aventurado opinar. Pueden ocurrir, sin embargo, grandes innovaciones tecnológicas, o la plena utilización de innovaciones recientes, que eleven nuevamente la productividad sin aquellos elementos de falsedad que indicamos al comienzo.

Sin embargo, la eliminación progresiva de tales elementos de falsedad va a requerir pesadas inversiones. Subirá pues la proporción de un nuevo tipo de acumu- lación energética y de defensa del medio ambiente en relación a la acumulación reproductiva. Si bien se trata de una acumulación de enorme importancia, ella no aumentará inmediatamente la productividad media del sistema; por el contrario, acentuará el descenso del ritmo de la productividad media y del ritmo de crecimiento del producto global.

Examinemos la incidencia de estos hechos. El descenso del ritmo del producto obligará inevitablemente a un descenso correlativo en el ritmo del consumo, pues si en vez de ello se comprimiera el ritmo de acumulación, haría más intenso aún el descenso del producto.

Esta incidencia adversa del consumo plantearía un difícil problema social y político. ¿A qué grupos sociales afectarían estos reajustes? ¿Qué mecanismos tiene el sistema para hacerlo?

Ante todo, téngase presente que aquellas inversiones relativas a la biosfera representan un mayor costo por unidad de producto, que las empresas trasladarán sobre los precios. En materia de petróleo, estos han subido inmediatamente por el encarecimiento de las importaciones, y un alza similar se reflejará progresivamente en el costo bastante más elevado de las nuevas fuentes energéticas. Pues bien, dado el poder de la fuerza de trabajo, sobrevendrá el alza de las remuneraciones y el empeño consiguiente de las empresas de proteger su excedente mediante una nueva elevación de los precios. ¿Habrá forma de evitarlo?

Es claro que si la fuerza de trabajo no tuviera poder sindical, o este fuera incipiente, no tendría por qué sobrevenir esa nueva alza de precios con la espiral consiguiente o su mayor impulso. La espiral es, en verdad, la consecuencia de una confrontación de poder. La política monetaria solo puede evitarla si las consecuencias adversas de una restricción monetaria sobre el empleo debilitan el poder sindical y político de la fuerza de trabajo y el juego del mercado hace descender los salarios. No creo que este sea el caso en los Estados Unidos, donde ese poder sindical y político, a pesar del desempleo, trata de contrarrestar el aumento de los precios con el de las remuneraciones. Más aún, estas tenderán a subir si además de la incidencia del petróleo actúan otros factores que llevan al alza de precios, entre ellos las consecuencias inflacionarias de los subsidios a los desocupados y también de otros gastos fiscales. Es el nuevo fenómeno de la estanflación, claro síntoma de los cambios que han sobrevenido en las relaciones de poder.

El problema podría resolverse momentáneamente si la fuerza de trabajo se abstuviera de compensar el alza de los precios con aumentos de remuneraciones. 
Sería lo que se proponen quienes preconizan alguna forma de pacto social. Reflexiónese, sin embargo, en lo que ello significa. Este sacrificio de los ingresos, con la consiguiente compresión del consumo, se haría para que los estratos sociales favorecidos pudieran seguir acrecentando su propia acumulación. ¿Se concibe que esto fuera una solución perdurable?

Es claro que si la fuerza de trabajo compensara estos efectos adversos con su propia acumulación, continuaría el proceso acumulativo; lo mismo podría decirse si el Estado desempeñara este papel compensador. Pero, evidentemente, no es así como funciona el sistema.

De estas explicaciones se desprende una conclusión de la mayor importancia, que conviene recalcar. Los mecanismos de captación y retención del excedente respondían racionalmente a las exigencias dinámicas del sistema en una estructura social donde gravitaba sin mayor contrapeso el poder económico, social y político de los estratos superiores. Pero ha dejado de ser racional cuando, por las mutaciones de la estructura social, se desenvuelve y afianza el poder sindical y político de la fuerza de trabajo, y se dilatan considerablemente los servicios del Estado.

Por lo demás, no parecería que tales mecanismos estén preparados para que las empresas puedan absorber aquellos mayores costos de producción comprimiendo su excedente, pues allí se encuentra la clave dinámica del sistema, según expresamos en otro lugar. Por cierto, una clave muy sensible, y además muy importante por el poder político de quienes la tienen en sus manos, principalmente en los estratos superiores.

Carezco de la posibilidad de cuantificar las dimensiones de este complejo problema. Acaso no sean desproporcionadas con relación al elevado nivel de consumo personal de Estados Unidos; pero es este solo un elemento del problema, pues la sociedad de consumo, que se ha extendido sobre toda la estructura social, si bien con grandes disparidades, ha adquirido un notorio impulso. Sin embargo, no podrá mantenerse el impulso, por lo menos durante un período muy difícil de transición.

Difícil no solamente por los factores internos en juego, pues la euforia generada por aquellas sociedad de consumo y las grandes dimensiones de los gastos del Estado han podido alcanzarse no solo gracias al extraordinario aumento de la productividad - al cual ha seguido un franco descenso-, sino a expensas del producto del resto del mundo, como ya expresamos. Este se vincula a otra de las grandes ilusiones que ahora se disipan: el poderío del dólar. Ha llegado, pues, el momento de abordar este aspecto.

\section{Reflexiones sobre el poderío del dólar}

La crisis del centro dinámico principal del capitalismo es también una crisis del apogeo financiero de los Estados Unidos, cuya dramática expresión es la caída del valor del dólar, cuya utilización como moneda internacional ha significado para los Estados Unidos una gran ventaja y una enorme responsabilidad.

Es la gran ventaja del señoreaje, es decir, el beneficio resultante de la creación de sus propios signos monetarios para responder al desenvolvimiento del intercambio mundial.

Esto acarreaba implícitamente la responsabilidad de regular la creación de aquellos signos monetarios con un claro sentido internacional, además de consideraciones internas.

Se ha cumplido con cierta eficacia esa responsabilidad antes de la inflación provocada principalmente por el déficit fiscal. Pero el déficit ha terminado por desquiciar todo el sistema monetario internacional y a ello se han agregado los efectos del alza del petróleo. Y el señoreaje se ha convertido en aquella ingente transferencia a Estados Unidos de una parte del crecimiento del producto mundial, como se dijo en páginas anteriores de este mismo capítulo.

Ya se había advertido de tiempo atrás las graves consecuencias del empleo del dólar como moneda internacional. Robert Triffin, el eminente profesor de Yale, lo advirtió con admirable insistencia. ${ }^{14}$

Dominaba en Estados Unidos la ilusión de un poderío ilimitado del dólar. Acaso esta ilusión contribuyó a que se acudiera a la expansión monetaria interna para cubrir los ingentes gastos de la guerra de Viet Nam que vinieron a superponerse a los cuantiosos gastos sociales de la "gran sociedad" del Presidente Johnson. Guerra notoriamente impopular, hacía difícil recurrir al empréstito o al impuesto para financiarla. ¿Por qué hacerlo, en verdad, si en vez de hacer recaer todo su costo sobre el consumo interno, la creación de dólares permitía captar gratuitamente una parte del producto del resto del mundo?

Hubo pues una extraordinaria inundación de dólares fuera de los Estados Unidos. Se habló entonces de una gran liquidez internacional: eufemismo que no atempera por cierto las graves consecuencias de este fenómeno.

Pero no fue eso solamente, ya que los dólares que así flotaban, multiplicaron sus efectos inflacionarios en

\footnotetext{
14 Véase su artículo "The International Role of the Dollar", Foreign Affairs, Vol. 57, $\mathrm{N}^{\circ}$ 2, Invierno 1978-79, donde el profesor Triffin, frente al desorden monetario internacional, lamenta comprobar que sus oportunas y severas advertencias no hayan sido escuchadas.
} 
el mercado de eurodólares. En efecto, los depósitos en dólares a favor de los países con superávit se emplean para prestar a otros países, de tal modo que a sus depósitos originales se agregan nuevos depósitos, con lo cual se intensifica la presión inflacionaria.

Estas operaciones parecen similares a las que ocurren dentro de un país a raíz de un incremento de dinero creado por su banco central. Hay sin embargo una gran diferencia, pues mientras este último tiene los medios para regular los efectos multiplicadores de esa creación inicial de dinero, tal mecanismo regulador no existe en el mercado de eurodólares.

Se ha llegado en esta forma a una verdadera aberración monetaria, que, además de los efectos referidos, llega a desvirtuar la política monetaria interna.

Debe admitirse, sin embargo, que no todo ha sido negativo en el mercado de eurodólares; han tenido un papel útil para hacer frente a los desequilibrios externos resultantes del súbito encarecimiento del petróleo. Como el Fondo Monetario Internacional no estaba preparado para hacer frente a necesidades de tan inusitadas dimensiones, los países afectados pudieron conseguir financiamiento en aquel mercado. En esta forma pudieron evitar una restricción de importaciones de otros bienes esenciales para mantener su actividad económica.

También han recurrido a sus facilidades los países socialistas de Europa Oriental, donde los gastos militares absorben una proporción considerable del producto global. En la Unión Soviética se calcula esta proporción entre 12 y $13 \%$, o sea, cerca del doble de la proporción de los Estados Unidos. Es obvio que ello es incompatible con la aspiración muy generalizada de acrecentar el consumo de la población y las inversiones necesarias. Tales países han recurrido, pues, al mercado de eurodólares.

Y no deja de ser paradójico que la inflación provocada en gran parte por los gastos militares de los Estados Unidos haya contribuido a aliviar, en cierta medida, el financiamiento de los mismos gastos en la órbita socialista.

De todos modos, los Estados Unidos siguieron lanzando dólares al mundo para hacer frente al agravamiento de su desequilibrio externo debido al alza del petróleo. Es muy explicable esta preferencia, pues si hubiesen recurrido al mercado de eurodólares, habrían tenido que pagar interés por sus préstamos, como lo están haciendo los otros países deudores. Como quiera que fuere, esta nueva creación de dinero y sus efectos multiplicadores aumentaron la presión inflacionaria en el ámbito mundial.

No cabe duda que esa expansión monetaria ha sido indispensable para evitar una seria contracción mundial, pero tampoco cabe duda que hubiera sido posible recoger los fondos así creados, pero no en forma de depósitos como en el mercado de eurodólares, sino invirtiéndolos en títulos internacionales que hubieran evitado los efectos multiplicadores de la expansión originaria. Pero tampoco estaba preparado el Fondo Monetario Internacional para este género de operaciones.

Es evidente que operaciones de esta naturaleza serían de carácter transitorio hasta que los países deficitarios, pudieran acrecentar sus exportaciones en la medida necesaria para cubrir el aumento de sus importaciones de petróleo.

Desde otro punto de vista, los Estados Unidos insistieron acerca de la necesidad de que los países con superávit aumentaran sus importaciones provenientes de ese país para contribuir a la corrección de su déficit. Para que ello ocurriera, tales países hubieran debido expandir su crédito sobre la base de sus acrecentadas reservas monetarias, y esto habría acentuado las consecuencias de la inflación de origen externo. Es pues comprensible que se siguiese más bien una política monetaria cautelosa. Si se hubiese procedido de otro modo, los países con superávit hubieran devuelto a Estados Unidos dólares que habían salido anteriormente. Sin embargo, así como al salir tales dólares aliviaron la presión inflacionaria interna difundiéndola hacia afuera, al transformarse ahora en demanda de importaciones habrían dado más intensidad a esa presión interna. De donde se comprueba una verdad muy antigua: no hay otra manera de corregir los efectos de la inflación provocada por el déficit fiscal que evitándola.

Acaba de decirse que los países con superávit habían optado por una política monetaria restrictiva. También tienen que acudir a ella los Estados Unidos en su empeño por frenar la inflación. En uno y en otro caso se sacrifica el crecimiento del producto que de otro modo se hubiera podido lograr. Tales son las consecuencias dinámicas contraproducentes por haber cubierto inflacionariamente el déficit fiscal: ¡agravar su incidencia sobre un producto que se encoge!

Sea como fuere, es indudable que el agravamiento de la inflación de aquel país no solo ha dado cada vez mayor amplitud a la espiral interna, sino que ha desatado externamente la espiral inflacionaria del petróleo. En el aumento originario de los precios de este último había influido, desde luego, la inflación que ya venía desenvolviéndose. Pues bien, el alza de precios vino a acentuar esta inflación y el deterioro del valor internacional del dólar. De esta manera se erosionaron de nuevo aquellos precios y también el valor de las considerables tenencias de dólares de los exportadores de petróleo. Y es bien 
sabido que esto condujo a estos últimos a encarecer nuevamente los precios. Compruébase de esta manera que, así como la aptitud de la fuerza de trabajo para resarcirse de los efectos adversos de la inflación impulsa la espiral interna, el poder recientemente logrado por los países petroleros les permite también resarcirse dando impulso a la espiral internacional.

\section{Incidencia de la crisis sobre la periferia}

Los países periféricos no exportadores de petróleo están sintiendo agudamente los efectos del alza de precios de este producto y, además, los de la elevación inflacionaria de los precios de sus importaciones provenientes de los centros.

Apenas podrían resarcirse de este deterioro de su relación de precios, elevando los precios de sus exportaciones, sujetas como están a una elasticidad ingreso relativamente baja de su demanda internacional.

La periferia tendrá, pues, que acentuar su empeño exportador de manufacturas, donde ha adquirido comprobada aptitud. Pero no cabría esperar que ello pudiera contrarrestar el resurgimiento de la tendencia al desequilibrio exterior, agravada ahora por el descenso del ritmo de crecimiento de los centros y el recrudecimiento de su proteccionismo.

Frente a ello, la sustitución de importaciones se ha vuelto ineludible, como lo fue durante otras crisis de los centros, sobre todo en la gran depresión. No es asunto de preferencias doctrinarias, sino una imposición de la realidad internacional.

Por claras razones de economicidad, la sustitución no debiera continuar en aquellos compartimientos estancos que ha impugnado la CEPAL ya desde sus primeros tiempos. Ahora más que nunca hay que hacerlo racionalmente en el ámbito latinoamericano y mediante fórmulas de intercambio con otros países en desarrollo.

Pero todo esto lleva tiempo y, mientras tanto, habrá que seguir haciendo frente al desequilibrio exterior. Se comprende muy bien que continuar acudiendo al endeudamiento en el mercado de euromonedas no es la mejor solución; pero tampoco hay otra mientras los países petroleros no adopten medidas compensatorias de los altos precios del petróleo con respecto a los países más afectados, como se viene discurriendo de largo tiempo atrás. En verdad, la proporción de petróleo que consumen tales países es de menor cuantía, lo cual no los dispensaría, en caso de compensación, de tomar severas medidas para economizar energía.

No cabe exagerar los efectos adversos que todo esto significa para la periferia. Su ritmo de desarrollo ha descendido, aunque menos de lo que hubiera ocurrido sin el endeudamiento. Terminaron los tiempos de bonanza cuando la tasa de crecimiento había llegado a sobrepasar un promedio de $7 \%$ anual.

Reflexiónese, sin embargo, en que esa tasa era aún insuficiente desde el punto de vista dinámico. Un análisis reciente de la CEPAL ${ }^{15}$ sostiene que para absorber el incremento de la fuerza de trabajo sería necesaria una tasa de 7,5\%. Perduraría pues la tendencia a excluir del desarrollo a grandes masas humanas relegadas en los estratos inferiores de la estructura social; y se acentuarían las tendencias conflictivas del sistema.

¿Qué significación tienen estos fenómenos? Muy serio, en verdad, lo que vuelve más imperioso el uso social del excedente. No cabe hacerse ilusiones, sin embargo, acerca de la posibilidad de esta transformación fundamental, pues ha de tomar un tiempo más o menos largo la tarea de persuasión doctrinaria así como la preparación política, Pero, de todos modos, parecería inevitable comprimir el consumo privilegiado, no solo para aumentar la acumulación, sino también para aliviar la incidencia del alza exterior de precios sobre la gran masa de la población. ¡Este objetivo mal podría lograrse acentuando la inflación!

Téngase presente, sin embargo, que mientras no se contrarreste la tendencia al desequilibrio exterior podría frustrarse, al menos parcialmente, esa mayor acumulación. No basta acumular más: hay que contar asimismo con la posibilidad de emplear los correspondientes recursos en la importación de bienes de capital que, al menos momentáneamente, no se pudieran lograr mediante el intercambio periférico.

A la luz de estas consideraciones, es evidente la necesidad de recursos financieros del exterior, con fines de acumulación. No cabe esperar una cooperación significativa de los centros en el período de transición que será necesario para superar la crisis. Por otro lado, los préstamos en euromonedas no podrían sustituir indefinidamente al financiamiento de las entidades de crédito internacional. Sobre todo si se introducen en ellas ciertas reformas, podrían constituir un mecanismo idóneo para encauzar cuantiosos recursos financieros del petróleo que ahora se emplean en aquel mercado o se revierten a los centros.

No se ha avanzado mucho en orientar esos recursos a la periferia, ni a través de tales entidades, ni en forma directa mediante inversiones realizadas por los mismos

\footnotetext{
15 "América Latina y la Nueva Estrategia Internacional del Desarrollo: enunciación de metas y objetivos”, E/CEPAL/L.210, 1979 (versión mimeografiada).
} 
países petroleros. ${ }^{16}$ Sería la mejor forma de reversión de recursos financieros a los centros en pago de importaciones de bienes de capital realizadas por la periferia con esos recursos: una reversión triangular.

Cabe aguardar, en este sentido, que ciertas iniciativas de formar multinacionales de países latinoamericanos, países petroleros y otros países en desarrollo puedan incrementarse; estas multinacionales podrían desempeñar un papel muy importante en dicha sustitución colectiva de importaciones, especialmente en bienes de capital y bienes intermedios de complejidad técnica. Esto abriría la posibilidad de una provechosa participación de los centros, de acuerdo con adecuadas reglas del juego.

\section{Transformación de la periferia y relaciones con los centros}

Por todo lo dicho queda claro que aunque las fuerzas democráticas consiguieran la transformación del sistema en la periferia, serían impotentes para cambiar por sí mismas la índole de las relaciones con los centros. No basta demostrar la incongruencia de estas relaciones y sus consecuencias adversas para la periferia. Acaso los desastres de la biosfera terminen por persuadir a los centros que el ejercicio de su poder hegemónico y el libre juego de las fuerzas económicas en el plano internacional acentúa las tendencias excluyentes y conflictivas del desarrollo de la periferia con muy serias consecuencias políticas; pero la periferia carece de poder. ¡Tiene poder, sí, para trastornar, pero no para transformar!

Solo una visión de largo alcance podría conducir a los centros a encarar sus responsabilidades mundiales; podrían desempeñar un papel importantísimo en la transformación. Hacerlo es algo que concierne a la periferia: hacerlo y cómo hacerlo. Sin embargo, los centros por su parte podrían contribuir notablemente al éxito de la transformación y también, conviene decirlo francamente, a su significación política.

¿Pero qué interés podrían tener aquellos para desempeñar ese papel? Han jugado sus cartas a favor de la sociedad privilegiada, movidos casi siempre por sus intereses de corto alcance. Y comprueban ahora que ese tipo de desarrollo se asienta sobre la inequidad social. Y acaso se persuadan también que en el curso avanzado del desarrollo solo es posible mantener la sociedad privilegiada de consumo con el ejercicio real o potencial de la fuerza.

Equidad social, democracia efectiva y clara vigencia de los derechos humanos son valores firmemente arraigados en los centros, después de muchas vicisitudes históricas. Compréndese pues ciertas manifestaciones de ansiedad y desconcierto cuando esos grandes valores humanos son menoscabados en la periferia. ¡Mas esto no impide que las trasnacionales demuestren su aptitud de acomodarse a esas claudicaciones políticas cuando no exaltan los méritos de un eclipse democrático!

\section{VIII}

\section{Ética, racionalidad y previsión}

\section{Privilegio y utopía del bienestar humano}

Por primera vez en la vida del planeta el portentoso desenvolvimiento de la técnica nos ofrece ingentes posibilidades de bienestar humano -y también de dignidad- no exentas de perniciosos efectos. Estamos al borde de la realización de una utopía; sin embargo, esas posibilidades están naufragando en la ambivalencia señalada y en el privilegio inherente a la estructura social de la periferia, así como a las formas de articulación con los centros.

\footnotetext{
${ }^{16}$ En momentos en que esto se escribe, informan los cables acerca de importantes decisiones que estarían dispuestos a tomar los países petroleros.
}

Es característica de todos los tiempos; en la larga trayectoria de la existencia humana, la vida afortunada de unos pocos se ha asentado siempre sobre el trabajo extenuante y la sujeción social de los muchos, apenas aliviados por una técnica rudimentaria de muy lenta evolución.

En verdad, dadas aquellas condiciones no cabía aguardar resultados ponderables en materia de redistribución del ingreso; tampoco, por cierto, una redistribución dinámica. La miseria parecía ineluctable. Y cabe preguntarse si la civilización occidental hubiera florecido sin la desigualdad. ¿Acaso Platón o Aristóteles, y tantos otros, no defendían la esclavitud? ¿Hubiera podido darse sin la desigualdad el esplendor del arte y la literatura, de la filosofía y de la ciencia, expresada a través de episodios brillantes y fugaces del talento humano? 
Como quiera que fuere, ha cambiado hondamente la significación del privilegio, pues ahora constituye un obstáculo formidable a la realización de esa utopía de bienestar humano. Y también al acceso de todos a las conquistas de la cultura, a la exaltación del abundante talento creador que se pierde con el relegamiento social de los desfavorecidos.

\section{La ética del desarrollo}

Es el privilegio del excedente. ¿A quién corresponde el excedente? Esta cuestión carece de respuesta científica, pues su respuesta es ética. Por su origen y naturaleza, pertenece a toda la colectividad y debe responder al interés colectivo.

Sin un cierto consenso ético no lograrán vigor perdurable los movimientos políticos de transformación. Pero tampoco sería posible lograr sus objetivos sin racionalidad, una racionalidad impuesta en última instancia por el desenvolvimiento de la técnica y su ambivalencia.

Dos siglos de creencia en las virtudes reguladoras de las leyes del mercado han contribuido también a sofocar la ética del desarrollo. Olvídase que Adam Smith fue profesor de ética antes de escribir su libro monumental; en verdad, hay una ética subyacente en sus razonamientos, así como en la doctrina neoclásica que le ha seguido. Todo ello se ha frustrado.

\section{Una responsabilidad conjunta}

En su empeño por conseguir la modificación de las relaciones con los centros, la periferia suele invocar la responsabilidad moral de aquellos. Sin embargo, la ética es indivisible. $Y$ dista mucho de haberse reconocido nuestra propia responsabilidad moral frente a la inquietud social del desarrollo periférico. Nada sólido podrá conseguirse sin una conjugación de responsabilidades.

Digámoslo sin reticencias: impulsados por su poder hegemónico cultivan los centros sus intereses inmediatos, económicos, políticos y diplomáticos, pero carecen fundamentalmente de aquella visión de largo alcance, de un sentido de previsión del futuro y de contención de su poder. ${ }^{17}$

Son dramáticas las consecuencias de la falta de previsión frente a los recursos energéticos. ¿Enseñará esta crisis a tenerla en la explotación y empleo de otros recursos naturales?

\footnotetext{
${ }^{17}$ Nada importante, nada realmente constructivo se ha hecho desde que los países en desarrollo comenzaron, hace dos decenios, a
}

¿Habrán aprendido los centros a contener su poder hegemónico? ¿Se han dado cabal cuenta que ello se impone para no perjudicar fatalmente sus propios intereses?

La falta de contención en el ejercicio de ese poder y una inconcebible imprevisión han llevado al caos monetario internacional.

También han prevalecido actitudes similares en las relaciones con la periferia.

¿Habrá que esperar una sucesión de crisis para que se modifiquen tales actitudes? ¿Esperan los centros defenderse del turbión social periférico que se está incubando?

Grandes y angustiosas incógnitas, todas estas, y de profunda significación mundial, provocan perplejidad y desconcierto en los dirigentes. Y parecería haberse perdido la aptitud para guiar y orientar ante la corriente de los acontecimientos, esa aptitud dirigente que siempre reclamaron las grandes vicisitudes históricas.

¿Qué hacer? No saben decirlo en los centros quienes tienen la responsabilidad teórica de esclarecer el camino y discurrir soluciones. ${ }^{18}$

Es también ingente la responsabilidad de la periferia. No creo, sin embargo, que nos encontremos aún preparados para cumplir una gran tarea de transformación, de donde el sentido último de estas páginas. Si logran provocar una discusión a fondo, si llevan a profundizar la significación de los hechos y discurrir cómo habríamos de actuar sobre ellos para conseguir los grandes objetivos del desarrollo, estas páginas habrán conseguido el propósito que las inspira.

Que no es solo asunto nuestro, sobra decirlo. En el empeño por esclarecer y persuadir hay que llegar también a los centros, quienes allí buscan afanosamente dar respuesta a los problemas del mundo de hoy, un mundo muy diferente del de ayer, tanto por las grandes posibilidades que ofrece como por los grandes riesgos que presenta. Posibilidades y riesgos que, unos y otros, debemos afrontar sin demora, sin que nos intimide la imagen del pasado. Pues también nos corresponde una clara responsabilidad moral al participar en esta gran aventura humana del desarrollo; al menos en las ideas quienes ya no podríamos hacerlo en la acción.

\footnotetext{
concretar vigorosamente sus posiciones frente a los países desarrollados. Ha prevalecido en estos, salvo algunas preclaras excepciones, una concordancia en actitudes negativas.

Compréndese pues la seria preocupación que ha venido dominándome en el curso de mi experiencia internacional, la preocupación de presenciar acontecimientos que van a la deriva.

18 Véase la carta de K. Galbraith al New York Times del 7 de mayo de 1979.
} 